\title{
MÉTODOS PARA CONTROLE DAS RACHADURAS DE TOPO EM TORAS DE Eucalyptus grandis Hill ex-Maiden, VISANDO A PRODUÇÃO DE LAMINAS POR DESENROLAMENTO
}

OSMAR JOSÉ ROMEIRO DE AGUIAR

Engenheiro Florestal

Orientador: Prof. Dr. IVALDO PONTES JANKOWSKY

Dissertaçāo apresentada a Escola Superior de Agricultura "Luiz de Queiroz", da Universidade de São Paulo, para obtenção do título de Mestre em Engenharia Florestal.

\author{
$P \mid R A C I C A B A$ \\ Estado de São Paulo - Brasil \\ Outubro - 1986
}


.ii.

Aos meus pais

Lourival e Osmarina

pela dedicação, amor e determinação na minha criação e formação

Aos meus irmãos

pela união familiar

OFEREÇO 
.iii.

A minha esposa Francisca

pelo companheirismo e compreensão

e

aos meus filhos

Diogo, Felipe e Deborah

pelas alegrias proporcionadas

DEDIDO 
HOMENAGENS

A Dra. CLARA MARTINS PANDOLFO

pelo entusiasmo em defesa dos recursos naturais da Amazônia.

Ao Dr. EDMUNDO NAVARRO DE ANDRADE pelo pioneirismo na Eucaliptocultura brasileira. 


\section{AGRADECIMENTOS}

- A todos aqueles que tiveram participação direta ou indireta na realização deste trabalho, expresso meus sinceros agradecimentos, em especial:

- Ao Prof. Dr. Ivaldo Pontes Jankowsky, pela orientação e amizade;

- Ampresa Brasileira de Pesquisa Agropecuária, pela oportụ nidade da realização do curso;

- Ao Instituto Brasileiro de Desenvolvimento Florestal, pelo apoio financeiro de parte desta pesquisa;

- Aos docentes do Departamento de Ciências Florestais pelo companheirismo, incentivo e em especial aos professores Dr. Hilton Thạdeu Zarate do Couto, Dr. Luiz Ernesto G. Bar richelo e Dr. Mário Tomazello Filho, pelas orientações e sugestões;

- Aos responsáveis pelo Centro Nacional de Pesquisas da Floresta pelo apoio prestado durante o desenvolvimento deste trabalho;

- Aos pesquisadores e funcionários do Instituto de Pesquisas e Estudos Florestais, em particular a Marialice M. Poggiani, pela orientação bibliográfica. 
- Aos funcionários e estarjiários do Denartamento de Ciências Florestais, nas pessoas dos senhores Ailton José de Melo, Benedicto Moysés S. Leite Filho, Clotilde M. B. Cuㅡ nha, José B. Tascare, José Francisco Teixeira, Francisco M. Oliveira e Paulo Camalionte;

- Aos colegas do curso de pós-graduação pela convivência saudável durante a realização do mesmo;

- A Empresa Champion Papel e Celulose S/A, pelo apoio logístico de campo e fornecimento das toras de Eucalyptus. grandis.

- As empresas Mobil Comércio Indústria e Serviços Ltda. , Gang Nail do Brasil e Yamoto S/A, pelas concessões de ma teriais para desenvolvimento deste trabalho. 


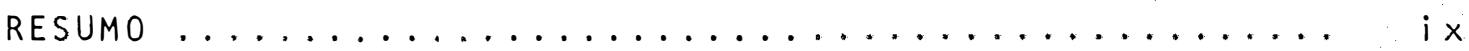

SUMMARY $\ldots \ldots \ldots \ldots \ldots \ldots \ldots \ldots \ldots \ldots \ldots \ldots \ldots \ldots \ldots \ldots \ldots \ldots \ldots \ldots$

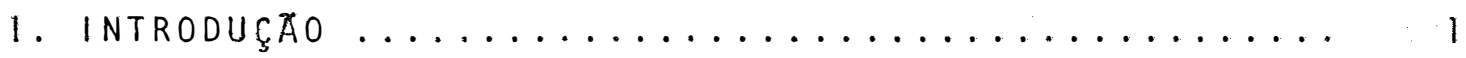

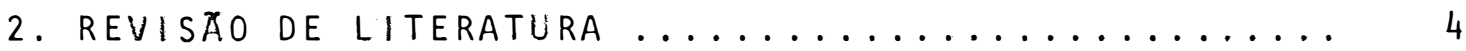

2.1. Utilização do gènero Eucalyptus .......... 4

2.2. Origem das tensões de crescimento ......... 9

2.3. Distribuição das tensões de crescimento nas

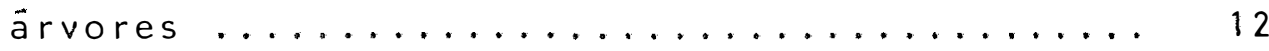

2.4. Manifestação das tensões de crescimento .... 19

2.5. Neutralização das tensões de crescimento e redução das rachaduras nos topos das toras... 26

3. METODOLOGIA ........................... 33

3.1. Espëcie utilizada ................. 33

3.2. Aplicação de tratamentos ............... 35

3.3. Avaliação das rachaduras de topo .......... 42

3.4. Determinação da densidade bàsica da madeira das toras de Eucalyptus grandis ......... 44

3.5. Anälise estatística .................. 45

3.6. Produção das lâminas ............. 47 
. viii.

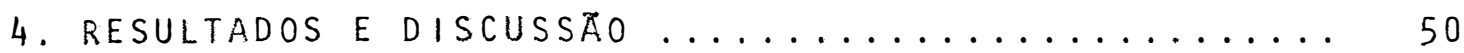

4.1. Densidade bàsica média da madeira das toras

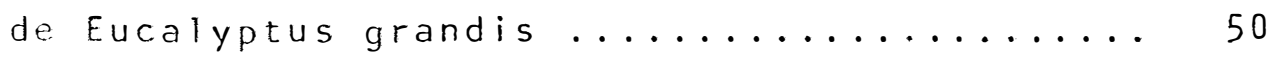

4.2. Avaliação das rachaduras de topo ......... 52

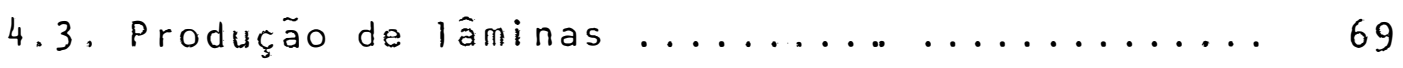

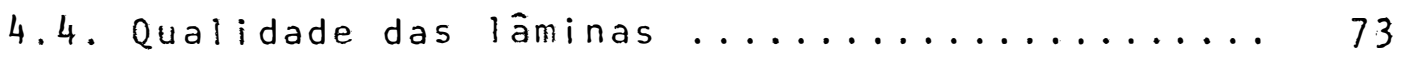

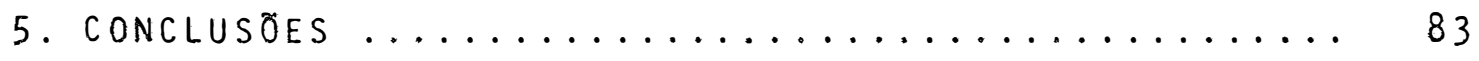

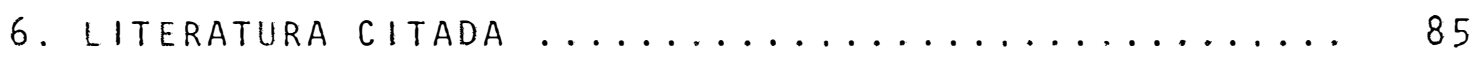


METODOS PARA CONTROLE DAS RACHADURAS DE TOPO EM TORAS DE Eucalyptus grandis Hill ex-Maiden, VISANDO A PRODUÇÃO DE LAMINAS POR DESENROLAMENTO Autor: OSMAR JOSE ROMEIRO DE AGUIAR
Orientador: PrOE. Dr. IVALDO PONTES JANKOWSKY

RESUMO

Neste trabalho estudou-se a possibilidade de controlar as rachaduras de topo em toras de Eucalyptus grandis Hill ex-Maiden, normalmente ocasionadas pela ação, conjụ gada ou não, das tensões de crescimento e de secagem. Desta maneira pretende-se viabilizar a utilização desta espécie como matéria-prima para produção de lâminas, pelo processo de desenrolamento em torno mecânico, para a posterior manufa tura de compensados.

Nos ensaios foram utilizadas 96 árvores com 13 anos de idade, procedentes de Mogi-Guaçu, Estado de são Paulo. De cada árvore retirou-se a tora basal, com 1,8 m de comprimento, para a aplicação dos diferentes tratamentos.

Foram testados dois tipos de corte e toragem das árvores, quatro proteções de topo, três métodos e dois tempos de armazenamento das toras. 
Pela análise da intensidade das rachaduras, $\underline{a}$ pós dois e doze meses de armazenamento das toras, concluiu-se que o corte e toragem das árvores com anelamento reduziu o aparecimento das rachaduras iniciais, e que a utilização de conectores do tipo Gang-Nail restringiu a evolução das mesmas. Dentre os métodos de armazenamento em água, tanto a imersão total como a aspersão intermitente mostraram-se mais eficientes na prevenção das rachaduras. Aos doze meses de armazenamento sob imersão total verificou-se uma diminuição das tensões de crescimento.

Apesar do alto indice de nós mortos as lâminas produzidas apresentaram caracteristicas visuais que permitem sugerir o Eucalyptus grandis como espécie de grande potencial para a manufatura de compensados. 
METHODS OF END-SPLITTING CONTROL IN LOGS OF

Eucalyptus grandis Hill ex-Maiden AIMING

AT THE PRODUCTION OF PEELED VENEERS

Author: OSMAR JOSE ROMEIRO DE AGUIAR

Adviser: Prof. Dr. IVALDO PONTES JANKOWSKY

\section{SUMMARY}

This work studied the possibility of controlling end-splitting on logs of Eucalyptus grandis Hill ex-Maiden which is usually caused by the action conjugated or not of growth and drying stresses. The aim was to determine the feasibility of using this species as raw material for the production of peeled veneer and the subseguent plywood manufacturing.

For the trials, 96 thirteen-year-old trees from Mogi-Guaçu, state of são Paulo, were felled. For the application of the different treatments a log ( $1.8 \mathrm{~m}$ long) was taken from the base of each tree.

A factorial experiment was set up and the following factors were tested; two kinds of tree feling and bucking, four topo protections, three methods and two periods of storage. 
According to the end-spliting intensity analysis, after two and twelve month following the log storage, it was concluded that the cutting and the bucking of trees with circunferencial grooves reduced the initial ende-splitting appearance, and the use of Gand-Nail type connectors lessened their evolution. Among the storage methods in water, both total immersion and intermitent aspersion proved to be more efficient in splitting prevention than air storage. Twelve-month storage under total immersion, it was observed a decrease on the magnitude of growth streses.

Notwithstanding the high incidence of dead knots, the veneer had visual appearances that makes it possible to suggest the Eucalyptus grandis as a species of great potential for the plywood manufacturing. 


\section{INTRODUÇÃO}

Atualmente o Brasil é o país que tem a maior área com florestas homogêneas de eucalipto no mundo (mais de 3.000.000 hal, e é possuidor de um amplo programa de pesquisa para o gênero.

Apesar do notável avanço obtido nas técnicas aplicadas à eucaliptocultura brasileira, pouco tem sido feito no que se refere a utilização de madeira maciça, principalmente nas indústrias de laminados, compensados e madeiras serradas.

Dentro da tecnologia dos produtos florestais, as principais linhas visam a produção de derivados da madeira como pasta celulósica, papel, chapas de fibras e a obtenção de energia.

A necessidade da diversificação no uso das mä 
deiras de reflorestamento, e a racionalização no aproveitamento das áreas plantadas foi reconhecida pelo Governo Federal, através do Decreto no 88.207 de 30 de agosto de 1983, onde o processamento mecânico passou a ser uma das prioridades a serem observadas na execução da politica de refloresta mento.

Pelas caracteristicas físicas e mecânicas, a madeira de eucalipto apresenta-se como uma das melhores opções de matéria prima para as indústrias madeireiras. Adicionalmente, em função do rápido crescimento das árvores, se rá possivel estabelecer programas de produção florestal próximos aos centros consumidores e evitar os sérios problemas de abastecimento.

Por ser o Eucalyptus grandis Hill ex-Maiden a espécie de mais. rápido crescimento e atualmente a de maior importância nos programas de reflorestamento dentre os eucaliptos, estudos e observações indicam-na como de grande potencialidade para as indústrias de processamento mecânico.En tretanto, a existência das tensões internas de crescimento e de secagem, responsáveis pelo aparecimento das rachaduras de topo das toras, tem inviabilizado a utilização do Eucalyptus grandis na produção de madeira serrada e laminados.

Se as tensões internas de crescimento forem neutralizadas e se as condições de armazenamento impedirem a formação de gradientes longitudinais de secagem, será possí 
vel contornar um dos principais obstáculos ao processamento mecânico.

Seguindo esse raciocínio, o presente trabalho teve como objetivo principal avaliar diferentes métodos para neutralizar tanto as tensões internas de crescimento como as posteriores tensões de secagem, visando dessa forma, evitar o aparecimento e a evolução das rachaduras de topo em toras de Eucalyptus grandis e possibilitar a produção de lâminas por desenrolamento. 


\section{REVISÃO DE LITERATURA}

2.1. Utilização do gênero Eucalyptus

Somente a partir da chegada da cultura européia, foi que a madeira do gênero Eucalyptus passou a ser utilizada, principalmente nas artes e folclore contemporâneo australiano. Naturalmente, a madeira dos eucaliptos nativos foi gradualmente sendo usada e empregada em produtos mais so fisticados e, com a utilização de novas tecnologias, tornou-se mais conhecida no mundo inteiro (HILLIS e BROWN, 1978).

Os eucaliptos, por suas caracteristicas de crescimento, vigor e agressividade (razões principais do seu notável êxito como espécie exótica), adaptam-se a variadas condições de clima, desde os semi-desérticos até aos tempera dos. Segundo a FAO (1981), o Eucalipto integrava importantes programas de recursos florestais de rápido crescimento em mais de noventa países. No início da década de oitenta, existiam experimentos com mais de duzentas espécies de 
eucaliptos, principalmente no Brasil, África do Sul e Estados Unidos, e mais de cem em outros paises. Porém, apesar da gama de espécies estudadas, somente poucas compunham gran des áreas de plantações industriais, por apresentarem caracteristicas favoráveis de utilização, tais como: E. grandis, E. saligna, E. globulus, E. camaldulensis, E. tereticornis, E. urophylla (alba), E. robusta, E. maculata, E.paniculata e E. Viminalis.

As madeiras das ārvores do gênero Eucalyptus prestam-se a usos variados como celulose e papel, madeira serrada, chapas aglomeradas, chapas de fibra, postes, etc., e desempenham papel especialmente importante na produção de energia, como recurso renovável. De um modo geral, as plantações com eucalipto no mundo estão divididas aproximadamente em: madeira para celulose (85\%), postes e madeira de menor qualidade (10\%) e madeira serrada (5\%) (FAO, 1981).

De acordo com costrA (1961), a introdução da eucaliptocultura no Brasil para a produção de madeira partiu da iniciativa privada, procurando resolver, principalmente seus problemas de origem energéticas. A expansão da eucalup tocultura originou-se das informações resultantes dos estudos desenvolvidos pelo Serviço Florestal da Companhia Paulís ta de Estradas de Ferro (C.P.E.F.).

Preocupada com a oferta de madeira necessäria para a utilização na forma de lenha nas suas locomotivas, a diretoria 
da C.P.E.F. criou, na primeira década do século XX, O Departamento Florestal que teve como seu primeiro chefe o Dr. Edmundo Navarro de Andrade. No ano de 1904 o principal objetí vo de Navarro de Andrade era indicar para o reflorestamento ao longo das linhas das estradas de ferro da Companhia as e pécies mais interessantes econômicamente. Testou, no Horto Florestal de Jundiaí, noventa e cinco espécies e entre elas, os eucaliptos, péroba, pinheiro do Paraná, jequitibá, cabreū va, carvalho português, casuarina e grevilha. Já em 1906, os eucaliptos despontavam como as espécies mais promissoras e a partir de 1909 passaram a participar dos programas de re florestamento como espécies definitivas (ANDRADE, 1961).

Conforme relatório preparado para a segunda Conferência Mundial do Eucalyptus, realizada em são Paulo no ano de 1961, era estimado que as plantações de eucalipto no Brasil ocupavam uma área de 560.000 ha, com 447.000 ha em São Paulo, 60.000 ha em Minas Gerais, 34.000 ha no Rio Grande do Sul, Santa Catarina e Paraná e 19.000 ha distribuidos entre outros estados; com as seguintes espécies: $\underline{\text { E. saligna }}$ (32\%); E. alba (18\%); E. citriodora (14\%); E. tereticornis (12\%); E. grandis $(9 \%)$; E. paniculata $16 \%$ ); E. robusta, E. brotryoides, E. resinifera, E. camaldulensis, E. propinqua , E. pimetata e outros $(9 \%)$. Essas plantações destinavam-se à produção de lenha, carvão para siderurgia, postes, moirões de cerca, estacas para fundações e edificios, dormentes, escoras de minas, chapas de fibras, pasta celulósica e papel 
(CONFERENCIA MUNDIAL DO EUCALIPTO, 1961).

A partir de 1966, com a criação dos incentivos fiscais ao reflorestamento, houve a necessidade de ampliação das pesquisas, que passaram a ser desenvolvidas a ní vel regional através da integração Universidade $\mathrm{x}$ Empresa. Neste periodo ocorreu um aumento significativo das áreas reflorestadas com eucalipto no Brasil, devido ao incentivo do governo (Tabela 1).

TABELA 1. Área reflorestada com eucalipto, incentivada pelo governo.

\begin{tabular}{lc}
\hline Ano & Area reflorestada - ha \\
\hline 1967 & 13.877 \\
1970 & 181.343 \\
1975 & 1.055 .023 \\
1980 & 2.293 .750 \\
1985 & 3.047 .682 \\
\hline
\end{tabular}

Fonte: ANCP (1984)

SBS (Carta-Consulta aprovada, 1985). Informação pes soal Roberto de Mello Alvarenga.

Apesar do avanço das pesquisas florestais no decorrer do século, favorecidas pelas caracteristicas ecoló- 
gicas do Brasil, muito pouco tem sido feito no que se refere a utilizaçáo dos eucaliptos nas indústrias de processamento mecânico da madeira.

Infelizmente, as toras de eucalipto apresentam algumas caracteristicas desfavoráveis, entre as quais as mais importantes são as tensões de crescimento, as contrações por ocasião da secagem, o colápso e as fibras reversas (FAO, 1981). Contudo, esses inconvenientes podem ser minimi zados através da utilização de técnicas adequadas.

Segundo MC Coube, citado por MAC MILLAN (1978), na Austrália são utilizadas diversas espécies de eucaliptos na produção de compensados, alguns com os mais altos padrões de qualidade, mas com baixo rendimento devido às rachaduras de topo originadas das tensões de crescimento.

Segundo FREITAS e PONCE (1979), a madeira dos eucaliptos é largamente utilizada para obtenção de fibra para chapas e celulose, como também para produção de carvão, postes e moirões. Contudo a produção de madeira serrada tem sido restrita e o principal obstáculo é o aparecimento, após o abate da árvore, das rachaduras de topo, originadas das tensões de crescimento.

Testando seis espécies de eucaliptos na manufatura de painéis compensados, JANKOWSKY e AGUIAR (1983), con cluiram que o principal problema durante a laminação era a 
presença das rachaduras de topo nas toras.

\section{2. origem das tensões de crescimento}

A Sociedade Americana de Florestais definiu as tensões de crescimento como forças encontradas nos troncos le nhosos verdes. Desta maneira, são distintas das tensões e deformações que ocorrem na madeira como resultado da elimina ção de água pela secagem (DINWOODIE, 1966). São características do crescimento natural das árvores e ocorrem igualmente tanto em folhosas como em coniferas (JACOBS, 1945).

Segundo DINWOODIE (1966), BOYD (1972), CHAFE (1979) e CONRADIE (1980), a primeira tentativa de explicar a origem das tensões de crescimento foi empreendida por Martley em 1928, ao observar as curvaturas que ocorriam após os cortes de pranchas de olmo. Martley considerou inicialmente que as tensões poderiam ser causadas pelo aumento do peso da ärvore durante o crescimento. Entretanto, após desenvolver alguns cálculos, concluiu que o peso da árvore produziria apenas pequenas fraçöes das tensões de crescimento.

KOEHLER (1933), considerou várias causas para as tensões tranversais, como o efeito alternativo de maior crescimento circunferencial do que o radial, a redução da turgidez do tecido mais velho, ou mudanças quimicas da made $\underline{i}$ ra mais antiga. 
Segundo DINWOODIE (1966), Münch em 1938, estu彑 dando as tensões na madeira de reação, sugeriu que tais tensões eram devido a contração das paredes celulares da madeira em tração, em função do inchamento das mesmas no sentido transversal através da deposição de substâncias sólidas nos espaços laterais intermicelares duṛante a lignificação. Com aumento da presssão ocorre o inchamento tanto da parede como o da célula e subsequente alteração na orientação da microfibrila. Apesar da hipótese de Münch ser originalmente desenvolvida para madeira de tração ela também tem sido usada para explicar as tensões de crescimento nos troncos de árvores normais e retas.

Segundo CONRADIE (1980), Jacobs em 1938 foi o primeiro pesquisador que sugeriu ser a origem das tensões 0 resultado de possivel encurtamento da nova camada de crescimento da madeira, e que esse fenômeno da mudança dimensional ocorre em um determinado estágio de desenvolvimento da célula.

JACOBS (1945), propõe uma teoria, a qual sub $\underline{\underline{S}}$ tituiu a sua primeira hipótese, de que as tensões de crescimento surgiram como uma reação à tensão da seiva.

A teoria de JACOBS (1945) foi criticada por BOYD (1950c), onde este autor considerou que as forças de sucção nas árvores são maiores nos topos e sendo assim, as tensões deveriam apresentar uma distribuição semelhante, o 
que não é o caso; como também, que as forças de sucção consi deradas para a formação de tensão são capazes de causar colapso nas fibras, o que também não acontece normalmente.

Em seus estudos, BOYD (1950c), concliu que a lignificação das paredes celulares é a origem primária das tensões de crescimento.

WATANABE (1965), em sua hipótese para explicar a contração longitudinal das células nas camadas exterio res da ārvore (a qual foi semelhante a de Münch, citado por DINWOODIE (1966) e confirmou as descobertas de BOYD (1950c)), considerou que a polimerarização da lignina na parede secundāria da célula causa o inchamento irreversível da parede celular, tanto no sentido transversal como longitudinal, de acordo com o ângulo da microfibrila nas camadas da parede. E'm função disso, postulou que as fibras podem alongar-se ou contrair-se como resultado de Iignificação.

BOYD (1972), deduziu que tensões de substancial magnitude, tanto longitudinal, radial e tangencial, são geradas nos tecidos da madeira como um resultado de lignificação das paredes celulares. 
2.3. Distribuição das tensões de crescimento nas árvores

Os troncos de todas as árvores são submetidos a um ligeiro encurtamento entre dois pontos quaisquer, próxi mos à periferia e no sentido longitudinal, quando crescem em diâmetro, o que impõe uma compressão axial na madeira interna em direção à medula (JACOBS, 1965). Este fenômeno deve-se a polimerização da lignina nos espaços inter-micro-fibri lares da parede secundária e que induzem a uma contração longitudinal da célula como resultado da sua expansão radial nas camadas de crescimento; de onde ficou estabelecido ser essa a origem das tensões de crescimento nos troncos das ärvores (BOYD, 1950C, 1972; WATANABE, 1965).

Estudando a distribuição das tensões internas de crescimento, JACOBS (1965), observou este mesmo fenômeno de deformação tanto nos troncos como nos galhos e raizes de eucaliptos.

JACOBS $(1938,1939$ e 1945), estudando o comportamento e distribuição das tensões de crescimento nos tron cos das árvores, preparou amostras longitudinais especialmen te posicionadas ao longo dos raios, na direção medula-casca, de árvores com vários diâmetros e de várias espécies, onde observou mudanças em extensão e tendências a curvaturas das amostras quando retiradas da prancha diamétrica (Figura 1). De suas observações concluiu que a madeira próxima à periferia da árvore estava sob tração longitudinal e no centro,prọ 


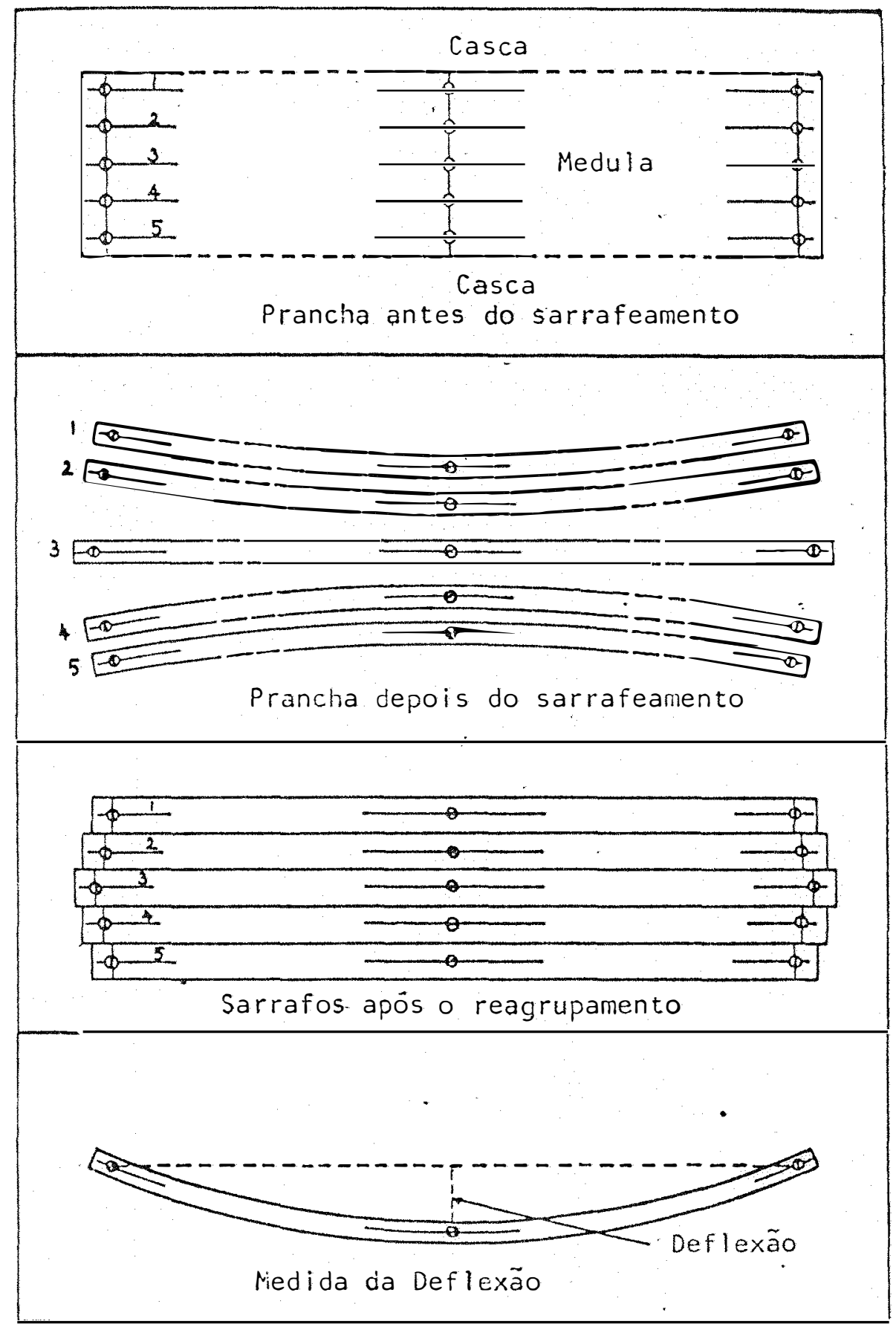

FIGURA 1. Preparação da prancha diamétrica para a medição das tensões de crescimento (JACOBS, 1945). 
ximo a medula, estava sob compressão.

Segundo JACOBS (1965) e BOYD $(1950 a, b)$, a distribuição das tensões de crescimento longitudinais variam de uma tração máxima na periferia até um valor zero por volta de $1 / 3$ do raio, seguindo em compressão crescente até a medula.

Como o crescimento em diâmetro das árvores e formado por novas camadas de células em diferenciação, surge no xilema, logo imediatamente ao cambio, a formação da tensão de tração longitudinal de crescimento. A magnitude dessa tensão é considerada baixa, quando analisada a nível de camada individual, mas que se torna máxima na periferia das toras pelo acúmulo das camadas de crescimento no sentido radial. Em virtude do novo xilema se encontrar em contato com o xilema diferenciado mais antigo (maduro), inicia-se progressivamente uma tensão de compressão longitudinal de crescimento no centro da tora, tornando-se na medula, conforme demonstrado na Figura 2 (MALAN, 1984).

Em algumas espécies o aumento do diâmetro e o efeito acumulativo das camadas sucessivas de crescimento em estado de tração induzem a parte central do tronco a uma com pressão superior ao seu limite elástico, causando o desenvol vimento de inúmeras fendas de compressão tanto na madeira co mo nas paredes das células, observadas pela primeira vez na 


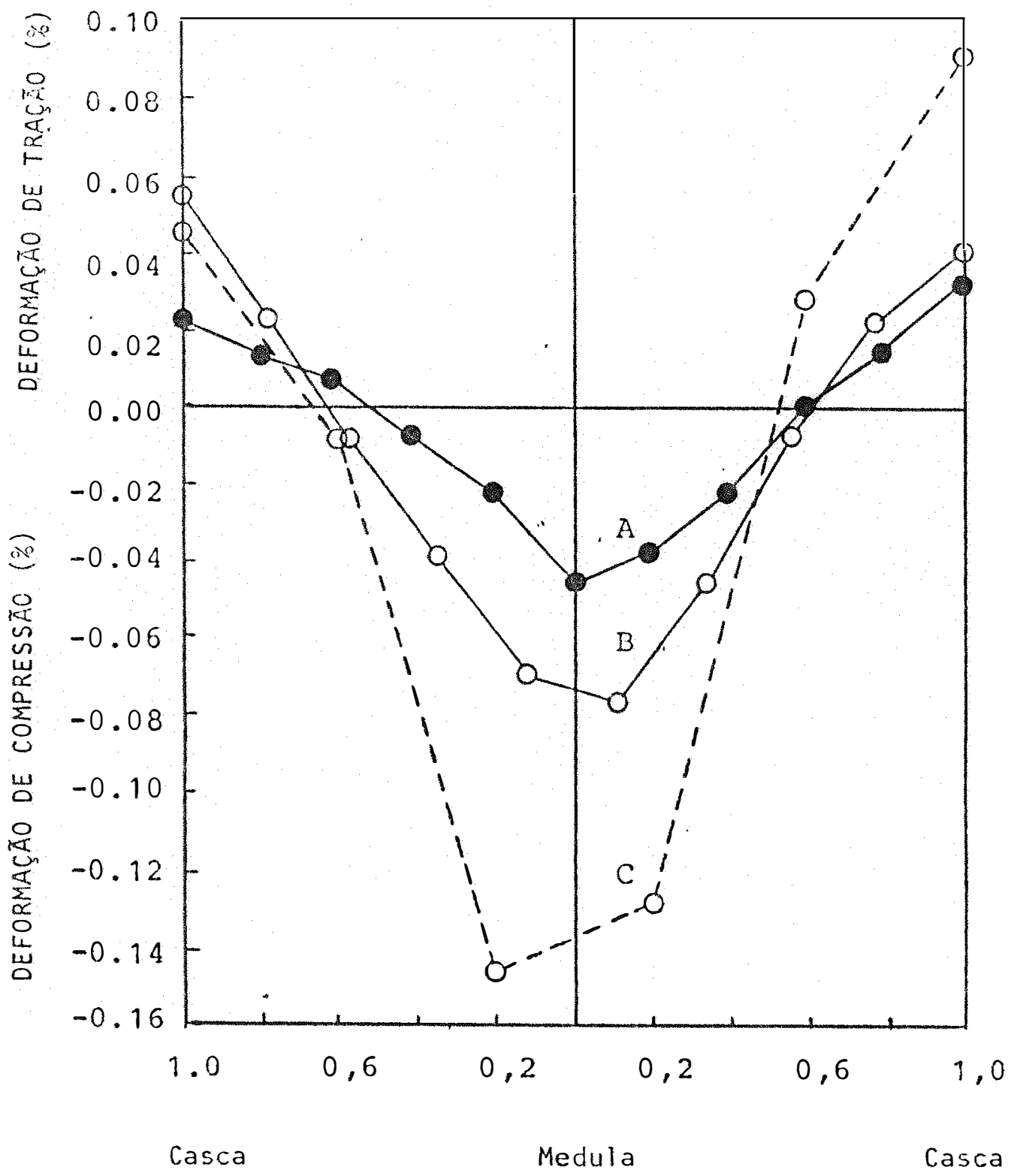

DISTANCIA RELATIVA DA MEDULA

FIGURA 2. Distribuição da deformação de crescimento em madei ra normal de Chamaecyparis obtusa (A), Cryptomeria japonica (B), e Quercus glauca (C), adaptada por MALAN (1984). 
Austrália e denominadas de madeira quebradiça ("brittleheart") (DINWOODIE, 1966 e MALAN, 1984).

Segundo VAN WYK (1978), as tensões de crescimento ocorrem naturalmente nas ärvores antes da derrubada, a tuando como uma forma de dar estabilidade à coluna pretensio nada. O referido autor apresentou uma analogia entre a tensão de crescimento, o suporte de arame de uma antena de TV e um pilar de concreto protendido (Figura 3).
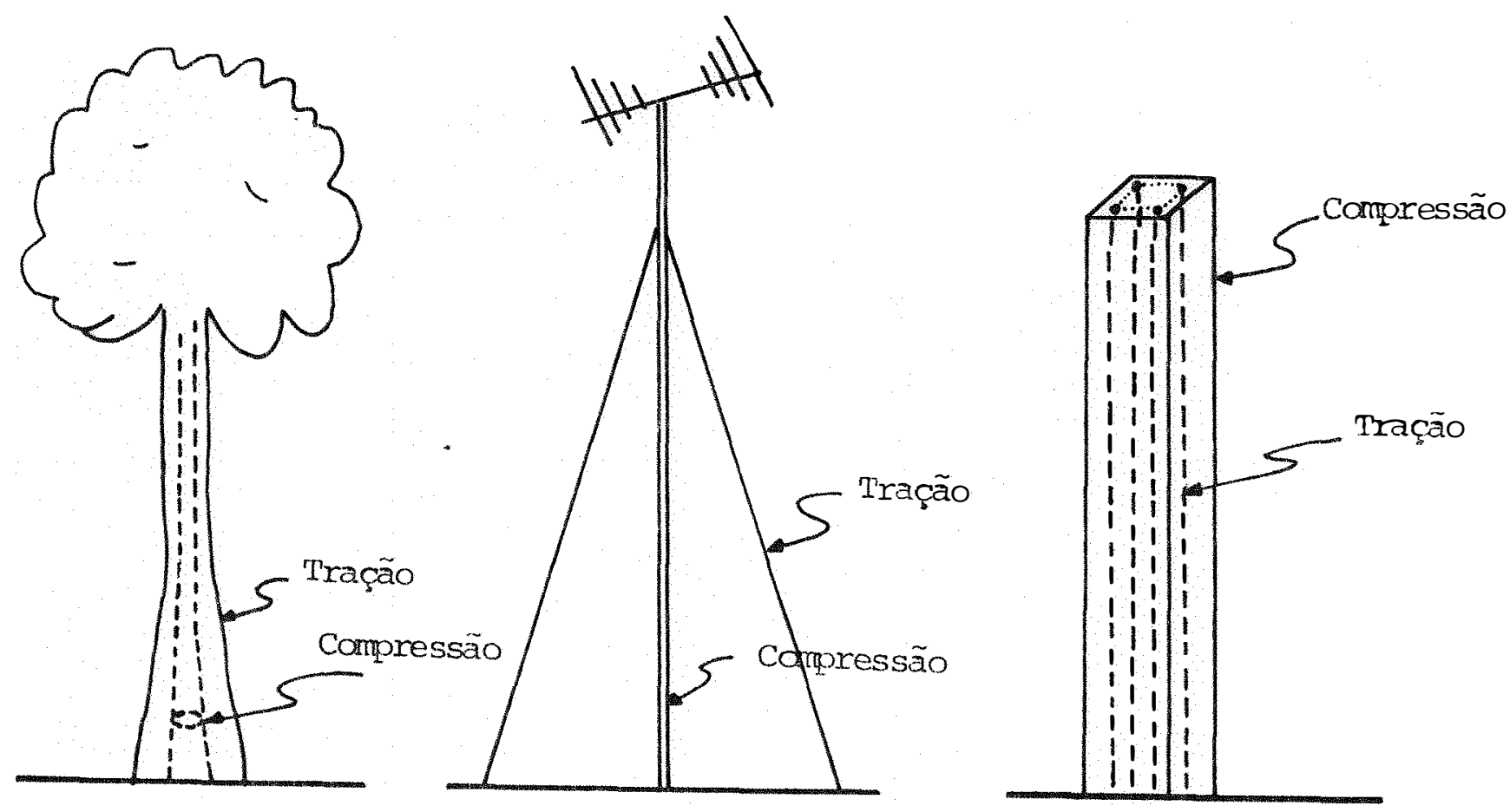

FIGURA 3. Relação entre as tensões de crescimento, os suportes de arame de uma antena de TV e os pilares de concreto protendido. (Adaptado de VAN WYK, 1978). 
Analisando-se as tensões transversais segundo JACOBS (1945), os tecidos próximos à periferia do fuste de uma árvore estão em estado de tensão de compressão tangencial e em consequência a madeirá interna em tração.

Citando Jacobs (1945), Boyd (1950), Gueneau (1973), Saurat e Gueneau (1976), HILIIS (1978), concluiu que as tensões transversais sãc muito menores do que as longitudinais e que as tensões tangenciais circunferenciais de compressão estão em equilibrio balanceado com as tensões radiais de tração.

Estudando as tensões de crescimento transversais JACOBS (1945) demonstrou, através de um corte em espiral da periferia em direção à medula em um disco retirado transversalmente de um txonco, que houve uma expansão das ca madas externas. O mesmo ocorreu quando um circulo externo de um disco foi cortado, enquanto o disco interno restante contraiu-se.

Examinando as tensões e deformações transversais, BOYD (1950a) encontrou resultados semelhantes aos suge ridos por Jacobs e considerou o fenômeno de três formas dife rentes: (1) "a distribuição da tensão transversal inicia-se das tensões circunferenciais primárias no crescimento das camadas de células"; (2) "as tensões secundārias desenvolvem-se da mudança na seção transversal das cëlulas induzidas pelas tensões primärias existentes na direção longitudinal"; 
(3) "as tensões secundárias transversais resultam da mudança na extensão das células que se encontram nas proximidades do corte transversal do tronco".

A magnitude das tensões internas de crescimen to foi apresentada por vários autores. Nos trabalhos realizados na Austrália com ärvores de eucalipto, as tensões de tração periférica longitudinal apresentavam valores médios entre 1,515 lbs/sq inch. $(10,438 \mathrm{MPa})$ a 2,060 lbs/sq inch. (14,193 MPa), conforme resultados determinados por JACOBS (1939), BOYD (1950a) e NICHOLSON (1973b). Valores semelhan tes foram encontrados em árvores de folhosa em florestas européias (Kubler, 1950a, citado por DINWOODIE, 1966).

As tensões correspondentes da compressão longitudinal no centro da tora, apresentavam valores na ordem de $2.000 \mathrm{lbs} / \mathrm{sq}$ inch. $(13,780 \mathrm{MPa})$ (JACOBS, 1965) a 5,000 lbs/sq inch. $(34,450 \mathrm{MPa})$ (TURNBULL, 1965).

A grandeza das tensões transversais apresenta vam valores para compressão tangencial variando entre 100 lbs/sq inch. $(0,689 \mathrm{MPa})$ a $400 \mathrm{lbs} / \mathrm{sq}$ inch. $(2,756 \mathrm{MPa})$, as quais são consideradas baixas, JACOBS (1945), BOYD (1950a) e Kubler (1959), citado por DINWOODIE (1966). Mas, por ocasião do corte transversal, as forģas longitudinais são trans feridas para o plano horizontal e, como consequência, ocorre um aumento maciço das tensões transversais, iniciando o aparecimento das rachaduras de topo das toras. 
2.4. AVALIACÃ̃O DAS TENSÕES DE CRESCIMENTO

As rachaduras de topo são as mais evidentes manifestações da existência das tensões naturais de crescimento, associadas ou não às tensões de secagem.

Segundo CHAFE (1979), o modo mais simples de avaliar o nivel geral das tensões de crescimento é, apös der rubar uma árvore, observar a evolução das rachaduras no topo seccionado transversalmente. Entretanto, é uma avaliação qualitativa, não exata e dependente do próprio nível de tensão, como também do diâmetro da árvore, de fendas centrais pré-existentes e do impacto da derrubada. É um método que altera o estado de equilíbrio das tensões que existem na ărvore e também impossibilita a repetição da medição por ser um método destrutivo.

Para a determinação da deformação de crescimento em uma peça de madeira é necessário medir na ärvore o comprimento do segmento, em seguida removê-la e efetuar uma nova medição. O valor para a deformação de crescimento longitudinal é representado pelo quociente da divisão entre a deformação encontrada e o comprimento inicial da peça medida no sentido longitudinal da árvore. Esse valor, quando multi plicado pelo módulo de elasticidade da madeira, é transforma do em tensão de crescimento longitudinal.

Quando se visa avaliar a distribuição da de- 
formação e da tensão de crescimento, efetuam-se estas operações sistematicamente para vários segmentos e em seguida ela bora-se um diagrama para a árvore.

Segundo POST et alii (1980) começam a surgir problemas quando pretende-se medir comprimentos de segmentos que não se encontram na superfície do tronco da árvore, e é preciso cortar a árvore antes da medição, o que permite uma redistribuição das deformações existentes naturalmente.

Os primeiros trabalhos visando a determinação da magnitude e variação das tensões longitudinais de crescimento nos troncos das árvores foram desenvolvidos por JACOBS (1938, 1939 e 1945), onde foram medidas as mudanças dos comprimentos das ripas retiradas das pranchas diamétricas no sentido longitudinal na direção medula-casca.

Apesar da utilização da prancha diamétrica ser um método bem conhecido, utilizado por autores como JACOBS (1965), WATANABE (1965) e Giordano et alii (1969) (cita dospor POST, 1980), e ter apresentado resultados mensuráveis sobre a distribuição das deformações e tensões longidutinais nas ärvores, vários pesquisadores vem chamando atenção para o efeito da redistribuição das tensões que ocorrem nas trans formações das toras em pranchas diamétricas e,como consequên cia os resultados das tensões não representam as mesmas magnitudes daquelas encontradas nas árvores em pé 
1973; Beck, 1974 e Vendhan e Archer, 1977, citados por POST, $1980)$.

Estudando as deformações de crescimento dentro das árvores de E. regnans, BOYD (1950a) utilizou toras com diâmetros entre 15 a 24 pol $(38,0$ a $61,0 \mathrm{~cm})$ e comprimen to de 18 a 26 pés $(5,50$ a 7,90 m). Mediu as deformações de crescimento para várias posições no raio dentro de uma cavidade retangular com aproximadamente $31 / 2$ pol $(8,9 \mathrm{~cm})$ de largura e 18 pol $(45,7 \mathrm{~cm})$ de comprimento, escavada no meio da tora para aliviar as tensões e medir as deformações. Cor tes sucessivos foram efetuados até uma distância muito próxi ma da cavidade. O total das deformações observadas nas vârias posições no raio corresponderam ao valor total das deformações longitudinais para a tora.

Visando desenvolver um método de rápida deter minação da tensão longitudinal de crescimento nas superficies das árvores em pé e das toras, visando comparar niveis de tensões entre ârvores para seleção em programas de melhoramento e também testar tratamentos de neutralização das ten sões em toras, NICHOLSON (1971) idealizou um método para medir tensão em pequenas áreas ao redor da circunferência dos troncos. Em amostras localizadas na superficie mediu três pontos no sentido axial e retirou, da tora, a amostra contendo simetricamente os três pontos. Após a remoção das amostras os pontos foram outra vez medidos e determinadas as de- 
formações como também as tensões de crescimento longitudinais correspondentes. Em seus estudos, NICHOLSON (1973a) uti lizou esta técnica na observação dos efeitos do armazenamento de toras sob aspersão d'água em três períodos de tempo.

Estudando o efeito da distribuição das deformações longitudinais na transformação das toras em prancha diamétrica e as mudanças dos comprimentos que ocorrem nas rî pas retiradas das pranchas, POST et alii (1980) propuseram uma extensão ao método de jacob, no qual as mudanças no com primento são medidas nas tábuas cortadas da tora e nas ripas das tábuas, onde concluiram que grandes erros podem ocorrer na distribuição das tensões longitudinais quando as medidas começam com as pranchas diamétricas e não nas toras.

Baseado nas informações de JACOBS (1939), de que a tensão de tração longitudinal das camadas mais novas de crescimento das árvores de E.gigantea é independente do diāmetro da árvore; e também assumindo que a tensão de tração longitudinal da madeira mais nova permanece constante através de todos os anos de crescimento da árvore, comprimindo o tecido interno mais velho uniformemente, Kubler (1959b) citado por WILHELMY e KUBLER (1973), chegou a uma distribuição teórica das tensões longitudinal de crescimento $[\sigma=$ $\sigma_{\alpha}(1+2$ ln $\left.\mathrm{r} / \mathrm{a})\right]$ e transversal ao tronco da árvore (Figura 4). 
onde:

$\sigma=e ́$ a tensão longitudinal de crescimento para qualquer raio da medula do tronco;

$\sigma_{\alpha}=$ é a tensão de tração longitudinal de crescimento da nova camada de crescimento da árvore;

$r$ = é a distância da medula para o ponto onde se deseja determinar o valor de $\sigma$;

$\mathrm{a}=$ é o comprimento total do raio da tora.

Vários trabalhos foram desenvolvidos tentando apresentar modelos matemáticos para determinar a distribuição das tensões de crescimento. Entre eles temos Boyd (1950a), Gillis (1973), Archer e Byrnes (1974) e Beck (1974), citados por MALAN (1984), mas as grandes reações contra os modelos foram baseadas na não consideração das variações das caracteristicas físicas e mecânicas da madeira, tanto no sentido transversal como longitudinal.

Considerando as variações das caracteristicas anisotrópicas da madeira, Post (1979) elaborou um modelo para distribuição das tensões longitudinal de crescimento bastante semelhante ao de Kubler (1959b), porém encontrou valores muito menores no centro da árvore, os quais estavam dentro dos limites de resistência à compressão da madeira (MALAN, 1984). Esses dois modelos são apresentados na Figura 5 . 


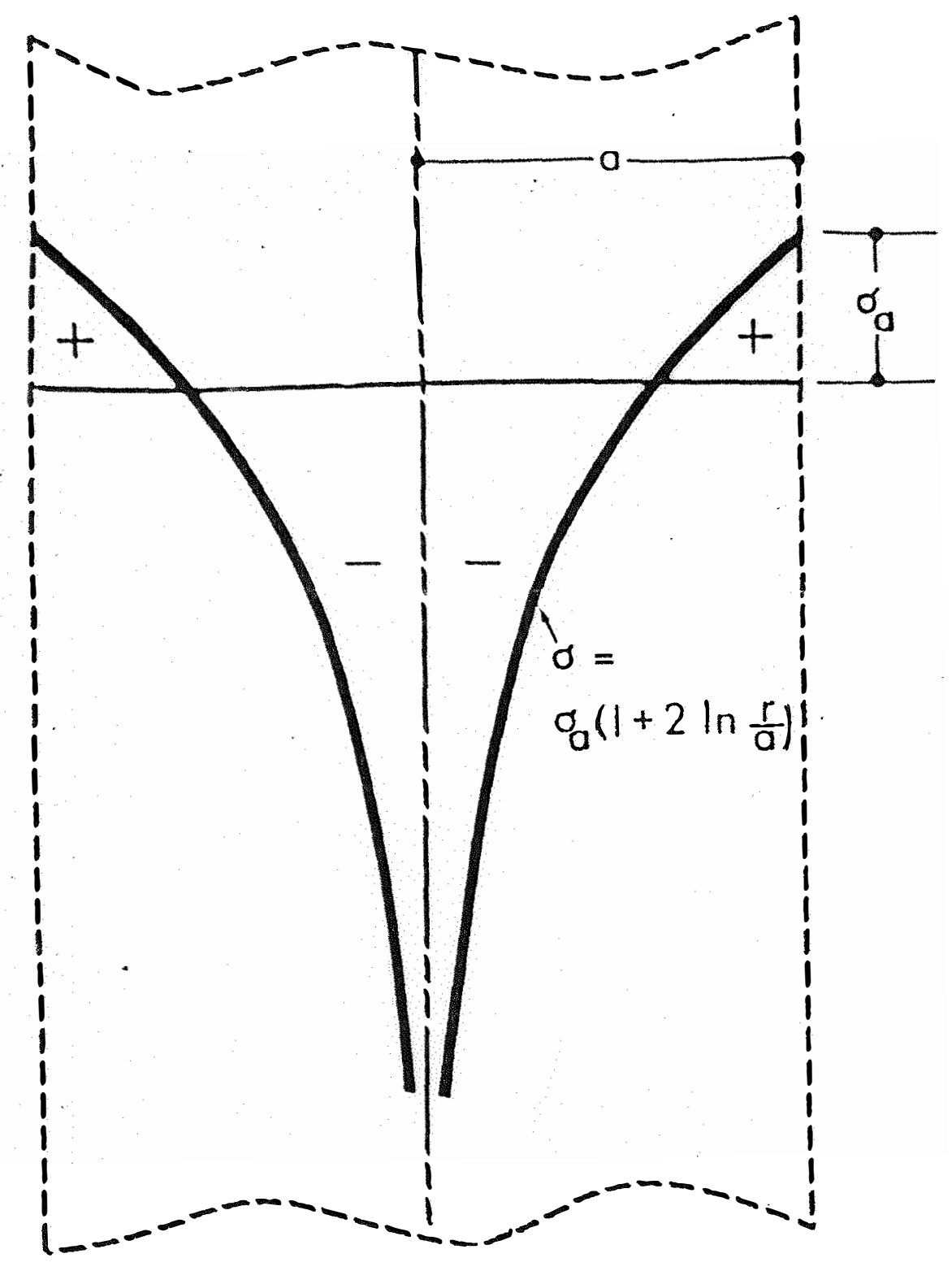

FIGURA 4. Distribuição teorica da tensão de crescimento em uma tora infinitivamente longa (WILHELMY e KUBLER, $1973)$. 


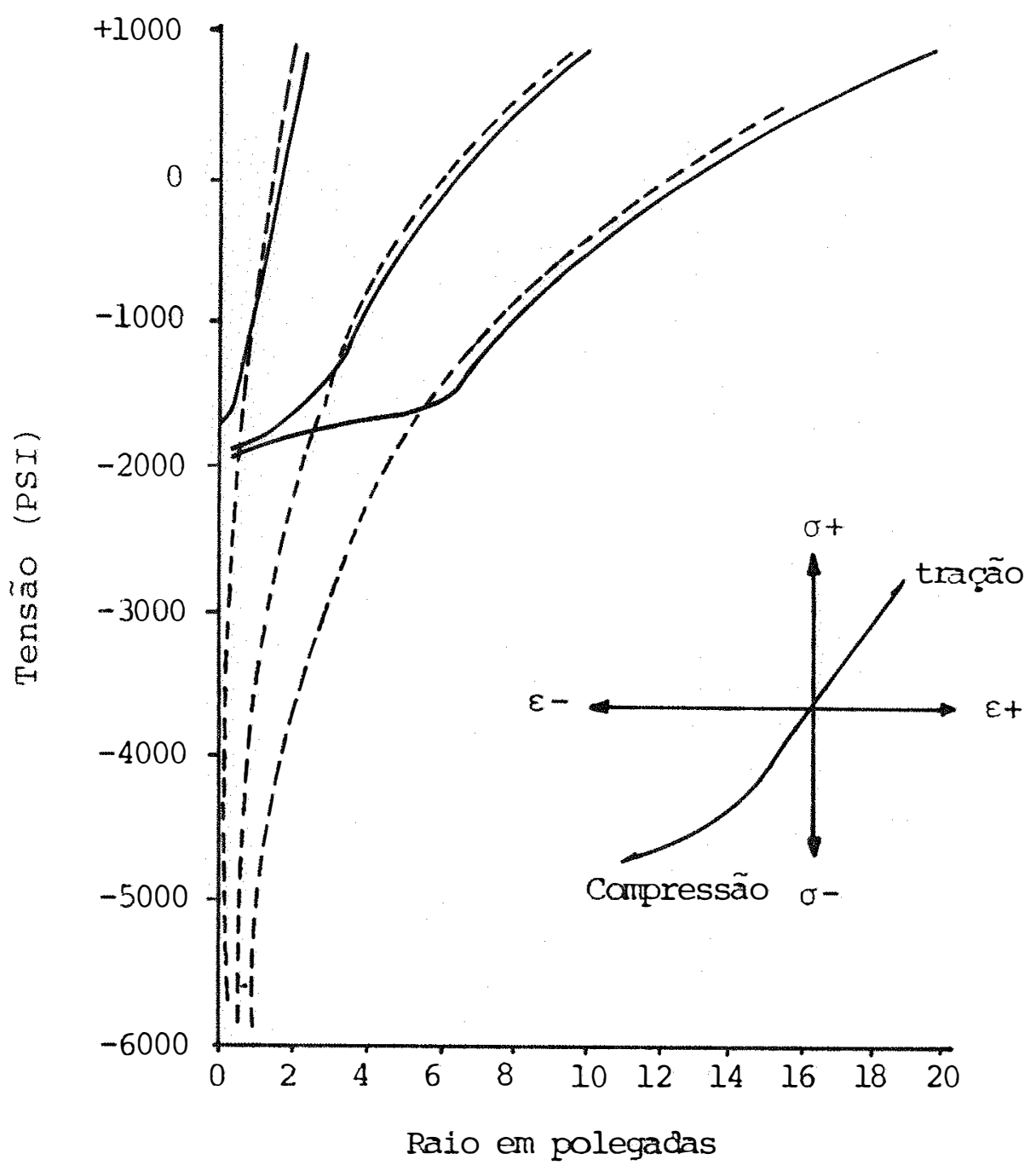

FIGURA 5. Distribuição das tensões longitudinal de crescimen to conforme os modelos de Post (-) e Kubler (--) adaptado por Post (1979). Fonte: MALAN (1984). 
2.5. Neutralização das tensões de crescimento e redução das rachaduras nos topos das toras

O ideal para a neutralização das tensões internas de crescimento seria a utilização de técnicas aplicadas nas árvores em pé, para reduzir as rachaduras que ocorrem por ocasião da derrubada da árvore e a sua transformação em toras, e também previnir a existência das falhas internas de compressão e as micro-fendas conhecidas como madeira quebradiça.

Várias tentativas foram realizadas, e entre elas temos a sugerida por CHAFE (1979), que se baseava na utilização de um processo de bloqueamento da lignina na árvore, como ocorre em certas espécies de macieiras ocasionadas por uma infeç̧ão virótica que resulta em uma deformação do tecido lenhoso conhecida por "madeira elástica". E dessa ma neira o autor espera que as tensões de crescimento nas árvores tratadas fossem extremamente baixas ou até mesmo inexistente.

Os trabalhos realizados por GIORDANO, CURRÓ e CHISIS (1969) e GIORDANO e CURRÓ (1972), onde foi testado o anelamento circunferencial do alburno da árvore em pé e deixadas no campo, apresentaram resultados com pouco efeito sig nificativo.

A técnica da secagem de ärvore em pé pelo ane 
lamento do alburno apresentou bons resultados na diminuição das rachaduras, conforme trabalhos de VILLIERS (1973) e NICHOLSON (1973a), porém a necessidade de um longo período de espera da árvore no campo pode trazer alguns inconvenientes para o processamento das toras, como a secagem superficial do tronco e ataques de fungos e insetos.

Waugh (1977), citado por CHAFE (1979), estudando o efeito do ritmo de crescimento na intensidade da ten são, testou em seus experimentos a utilização de herbicidas desfolhadores e encontrou uma diminuição de $20 \%$ quando compa rada com a testemunha.

Para o corte das árvores várias sugestões tem sido apresentadas, como as de Perkitny et alii (1951), Mayer e Weglin (1955), citados por CHAFE (1979), que seria de cortar o tronco próximo ao solo e incorporando o mais que possivel as raizes suportes, com o próximo corte transversal feito acima de 6 metros e, se possivel, contendo uma bifurcação de galhos.

A utilização de braçadeiras metálicas seria um método teoricamente efetivo, porém os trabalhos de VILLIERS (1973), na África do Sul, apresentaram várias dificulda des, e como solução o autor sugeriu o uso de um dispositivo de tiras elásticas onde se poderia aplicar a mesma tensão de compressão continuamente na tora. 
Estudando os efeitos das tensöes de crescimen to e o impacto da derrubada da ārvore no surgimento das racha duras de topo, Barnacle (1973) e Barnacle e Necesary (1978)(ci tados por MALAM,1984), sugeriram que as rachaduras de topo seriam resultados das falhas existentes internamente na ärvore (devido as altas tensões de crescimento que reduzem a sua resistência natural) e apresentam uma correlação entre o impacto da derrubada e a ocorrência de fendas em anel no centro de tora.

Segundo os trabalhos de Tisseverasinghe (1967) Mayer e Weglin (1955), citados por MALAN (1984), a utilização de peças metálicas fixadas na face do topo das toras como Gang Nail, prendedores em forma de S e C, após o corte transversal, não reduzem as tensões internas de crescimento, porém restringem o desenvolvimento das rachaduras deixando - topo intacto até que o processo de secagem aumente a resis tência à tração radial e contrabalance a tensão interna.

Após analisarem teoricamente as várias formas de aliviar a tensão de crescimento antes do corte transversal das toras, BARNACLE e GOTTSTEIN (1968) testaram três téc nicas de anelamento circunferencial com motoserra em toras de E. crypellocarpa e E. regnans, conforme Figura 6. Concluiram que a primeira técnica resulta em proteção para as faces de ambos os topos expostos pelo corte transversal, e tanto a segunda como a terceira protegem somente uma das faces. 

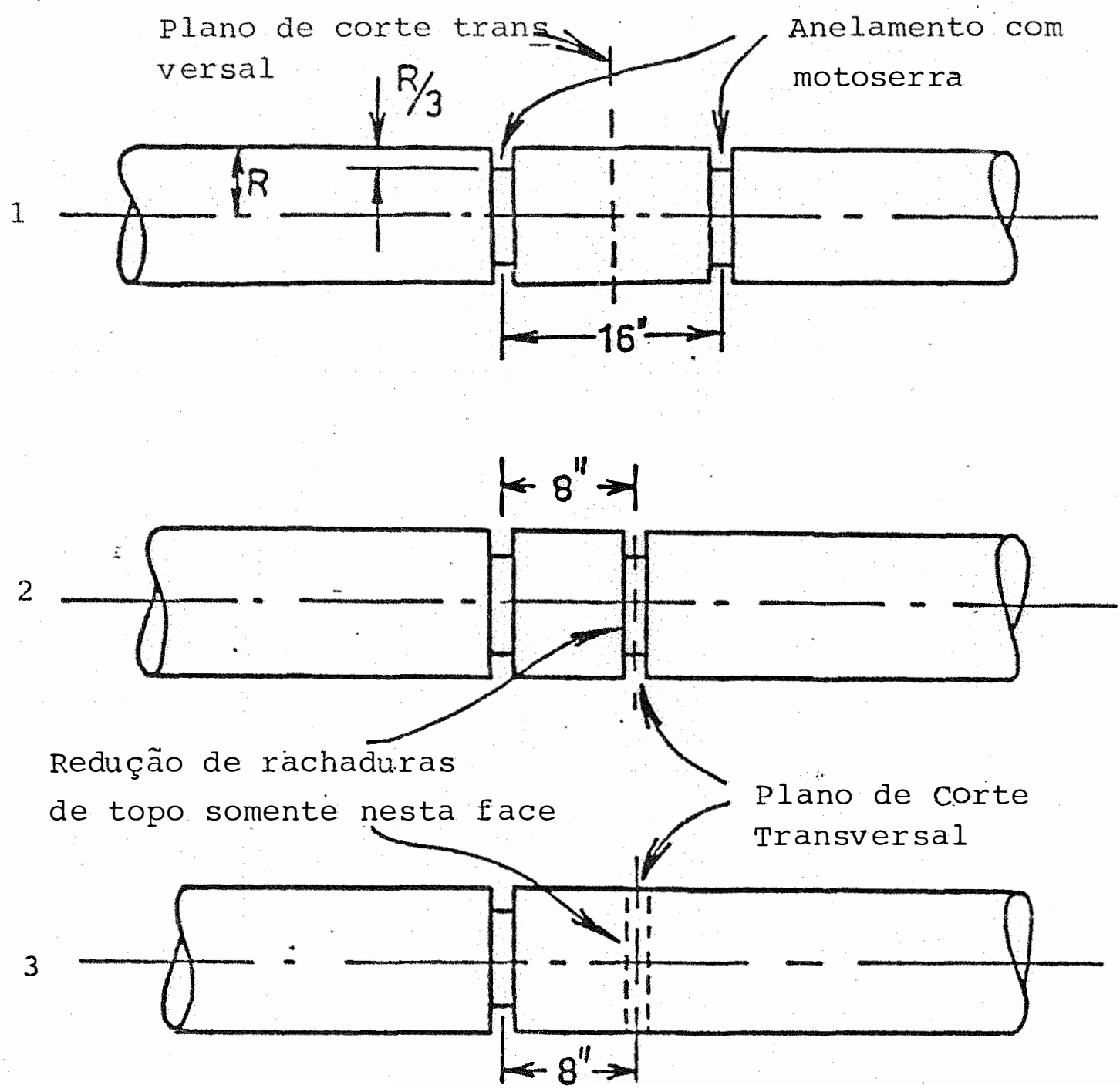

FIGURA 6. Técnicas de corte utilizando-se o anelamento com motoserra visandoo alivio das tensões de crescimen to no topo das toras. BARNACLE e GOTTSTEIN (1968). 
VAN WYK (1978) mostrou na África do Sul que o anelamento circunferencial com motoserra a uma profundidade variando entre 2,5 e 4,0 cm e a uma distância do corte transversal correspondente a $1 / 3$ do diâmetro, redistribuirá as tensões, podendo ser a tora processada na serraria den tro de um período de 30 dias.

CONRADIE (1980), estudando a possibilidade da neutralização das tensões nos topos das toras de E. grandis, visando a utilização desta madeira na indústria de compensados, testou o anelamento superficial com três profundidades de corte e três distância entre o anelamento e o corte trans versal. Concluiu que os valores das rachaduras diminuiram com aumento da profundidade e com a distância do anelamento para o topo da tora.

Barnacle (1971) e Imam e Heikal (1972), citados por MALAN (1984), demonstraram que as tensões de secagem interagem com o alívio das tensões de crescimento para causa rem rachaduras, e que em alguns casos estas rachaduras iniciam-se a menos de 20 minutos após o corte, principalmente quando são utilizadas árvores de eucaliptos suscetiveis a co lapsos. Este efeito pode ser minimizado por aplicação de soluções nos topos para dificultar a saida de água imediatamente após o corte.

No processo de secagem natural o topo seca mais rapidamente do que o restante da tora, e começa 
trair-se quando a umidade torna-se inferior ao ponto de satu ração das fibras. Inicia-se neste momento a formação de ten são provocada pela retração, concentrada em poucos centímetros de madeira seca. Quando esta tensão for superior a resistência da própria madeira surgem as rachaduras, que vão se aprofundando na tora a medida em que a secagem progride. O fenômeno foi confirmado pelos trabalhos de BOYD (1950b) e Mayer, Wigelin e Mammen (1954), citados por CHAFE (1979).

Em seus estudos tentanto reduzir as rachaduras das toras, Skolmen (1965), citado por CHAFE (1979), apli cou uma emulsão de cera no topo, onde conclui que este tratamento não era tão eficiente quanto a aspersão d'água.

NICHOLSON (1973a) após armazenar toras por 300 dias sob aspersão d'água não encontrou aumento significativo nas rachaduras đe topo, porém encontrou uma diminuicão signi ficativa na tensão periférica de tração nas toras em tratamento.

Segundo CHAFE (1979), Stubbings (1973) examinando vários métodos para redução de rachaduras em postes de E. grandis, concluiu que não houve diferença significativa entre os tratamentos com Gang Nail, anelamento e retenção de um colar de casca no topo da tora, após o descascamento da parte central da tora. Porém, o colar de casca foi o mais sim ples, barato e menos destrutivo. 
Estudos realizados no Brasil por GERALDO e SO DRE (1983) com objetivo de comparar vários dispositivos para Eucalyptus saligna e seus hibridos, concluiram que os conectores anti-rachaduras tipo Gang Nail foram o que mais contri buiram para a redução das rachaduras do topo dos postes.

SHOLMEN (1966) e KUBLER (1959c) mencionaram a possibilidade do alivio das tensões de crescimento nas toras verdes pela aplicação de aquecimento e umidade para plastifi car a lignina na madeira. Segundo os autores, o amolecimen to expandirá ou contrairá a madeira em resposta às tensões; mas também pode ser, em certos casos, responsável pelo desenvolvimento das rachaduras de topo e é considerada a principal desvantagem deste método de alivio. 


\section{METODOLOGIA}

3.1. Espécie utilizada

Para o desenvolvimeto deste trabalho utilizaram-se toras de Eucalyptus grandis Hill ex-Maiden, coletadas no municipio de Mogi-Guaçu, Estado de São Paulo, em floresta de propriedade da Champion Papel e Celulose S/A, e transportadas para o Campus da ESALQ/USP, em Piracicaba-SP.

As principais caracteristicas da floresta são:

- Espécie: Eucalyptus grandis

- Origem e procedência: Coff's Harbour. N.S.W. Austrália

- Data do plantio: janeiro de 1969

- Espaçamento inicial: 3,0 m x 2,0 m

- Desbastes: junho de 1978

- Intensidade de seleção: 1:10 
- Número atual de árvores/ha: 160

- Area do talhão: 2.843 ha

- Data de retirada das toras: 02.02.84

Visando-se utilizar árvores com a mínima variação fenotípica efetuou-se o levantamento de diâmetros (DAP) de 451 árvores em uma área de topografia relativamente plana, e em seguida elaborou-se uma curva de distribuicão diamétrica, cujos resultados são apresentados na Tabela 2 .

TABELA 2. Distribuicão das classes dos DAPs no talhão selecionado para extração da madeira utilizada no experimento.

\begin{tabular}{cccc}
\hline No classe & Intervalos $(\mathrm{cm})$ & No de árvores \\
\hline 1 & 19,4 & 26,0 & 25 \\
2 & 26,1 & 33,0 & 135 \\
3 & 33,1 & 40,0 & 196 \\
4 & 40,1 & 47,0 & 81 \\
5 & 47,1 & 54,0 & 14 \\
\hline
\end{tabular}


Considerando-se as características da variação dos diâmetros na população, optou-se pela classe 3, utilizando-se para o estudo 96 árvores com DAP variando entre $34 \mathrm{~cm}$ e $38 \mathrm{~cm}$.

3.2. Aplicação de tratamentos

Como o objetivo deste trabalho foi a verifica ção experimental das condições de corte, proteção de topo, armazenamento e tempo de armazenamento das toras de Eucalyptus grandis para posterior obtenção de lâminas desenroladas, testaram-se os seguintes tratamentos: dois tipos de corte para derrubada e toragem das árvores, quatro formas de prote ção nos topos das toras, três métodos e dois tempos de armazenamento das toras, totalizando 48 combinações em um delineamento fatorial.

\section{a. cortes e toragens das árvores}

Para poder avaliar o efeito dos cortes e das toragens das árvores no aparecimento das rachaduras de topo foram efetuados dois tipos:

a.1. corte industrial (Corte I)

Consistiu no corte normalmente utilizado, o que resulta na abertura de boca ou direção e em seguida 
corte de queda, sendo retirada uma tora da base de cada árvo re.

\section{a.2. corte com anelamento (Corte II)}

Antes da derrubada foi efetuado o anelamento com motoserra, a uma profundidade correspondente a $1 / 3$ do raio e $30 \mathrm{~cm}$ acima do local do corte. Após a derrubada, antes do corte para obtenção da tora, efetuou-se outro anelamento a uma distância de $1,20 \mathrm{~m}$ do anelamento anterior (Figu ra 7).

b. proteção de topo

Para estudar o efeito das proteções de topo no aparecimento de rachaduras, foram desenvolvidos quatro tratamentos:

b.1. testemunha (Proteção I)

As toras foram produzidas, com e sem anelamen to e não receberam nenhum tratamento de topo.

\section{b.2. cera (Proteção II)}

As toras receberam nos topos uma camada de Mobil CerM, um produto hidrossolúvel a base de parafina, pro duzido pela Mobil do Brasil. 


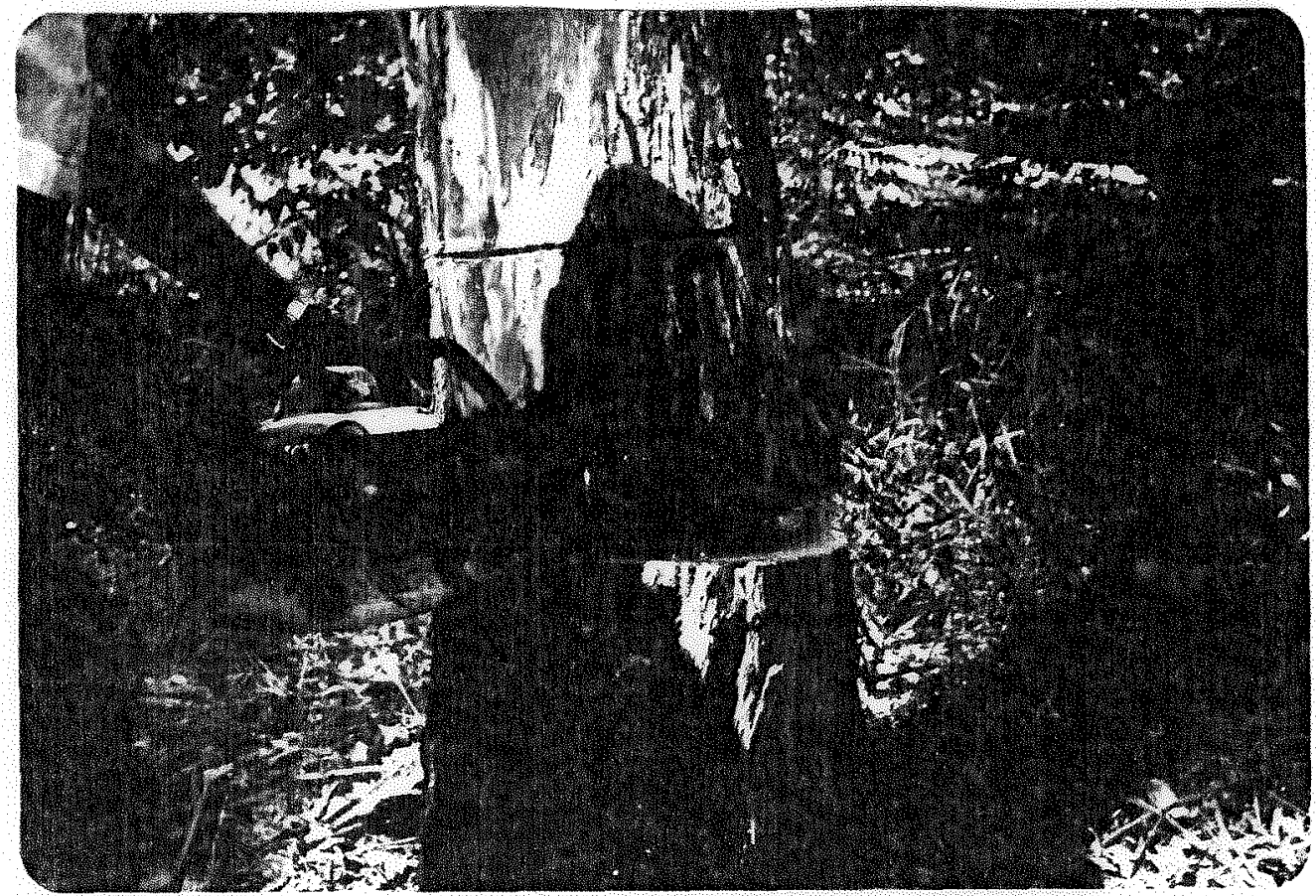

FIGURA 7. Operação de corte da árvore de Eucaliptus grandis. Detalhe do corte utilizando-se o método de anelamento (Corte II). 


\section{b.3. Gang Nail (Proteção III)}

As toras receberam nos topos uma placa de fer ro galvanizado conhecida comercialmente por Gang Nail com $12,9 \mathrm{~cm} \times 14,2 \mathrm{~cm}$, produzida pela Gang Nail do Brasil (Figura 8$)$.

b.4. Gang Nail x cera (Proteção IV)

Consistiu na combinação dos tratamentos b.2 e b. 3 , com as toras recebendo, nos topos, uma camada de cera e uma placa de Gang Nail.

Todos os tratamentos, tanto os de corte como os de proteção de topo, foram efetuados no campo. Quatro dias após a derrubada as toras foram transportadas em caminhões para Piracicaba, distante $80 \mathrm{~km}$ da floresta.

\section{c. armazenamento de toras}

Para poder-se avaliar o efeito do armazenamen to e o da secagem na evolução das rachaduras de topo, foram efetuados três tipos de armazenamento de toras.

C.1. imersão em âgua (Armazenamento I)

As toras foram armazenadas totalmente submersas em água, dentro de um tanque de ferro com $9,6 \mathrm{~m}^{3}$ de capa cidade. 
.39 .

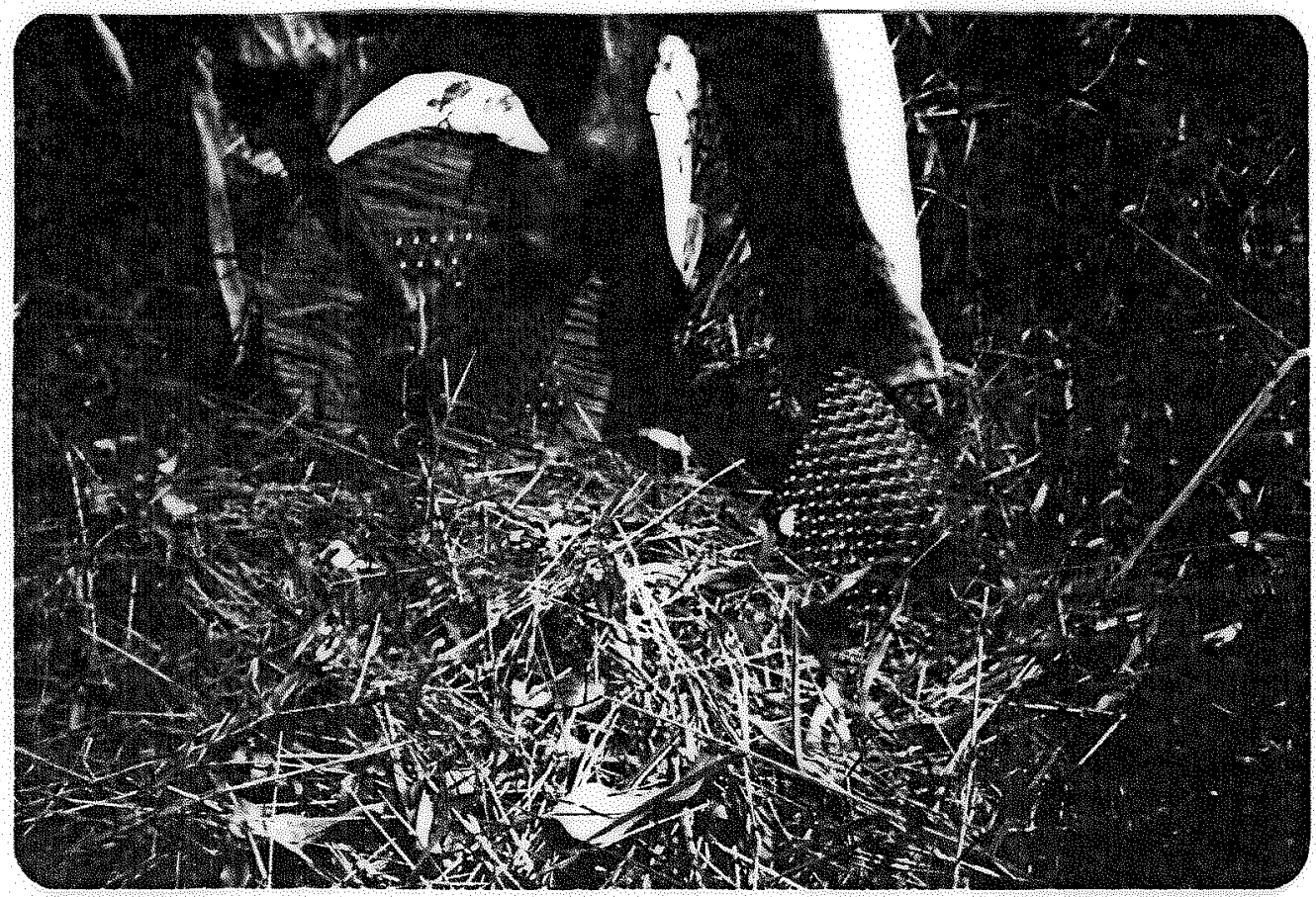

FIGURA 8. Aplicação do tratamento Proteção III. O conector Gang Nail é aplicado em ambos os topos da tora,com auxilio de martelo. 
As toras foram empilhadas e mantidas sob aspersão intermitente de água, com períodos de 15 minutos em a ção e 15 minutos parado (Figura 9). O sistema de aspersão compunha-se de dois bicos aspersores acionados por um contro lador automático de tempo ("time switch").

\section{c.3. ao ar (Armazenamento III)}

As toras foram simplesmente empilhadas ao ar, sem cobertura ou qualquer proteção.

\section{d. tempo de armazenamento}

Com objetivo de se avaliar o efeito do tempo de armazenamento na neutralização das tensões internas, como tambëm acompanhar a evolução das rachaduras nas toras, foram estabelecidos dois períodos para as avaliações.

As avaliações consistiram na quantificação das rachaduras, e foram efetuadas em:

d.1. (Tempo I) após 60 dias de armazenamento, em 50\% das toras;

d.2. (Tempo II) após 360 dias, nos $50 \%$ restan tes das toras. 


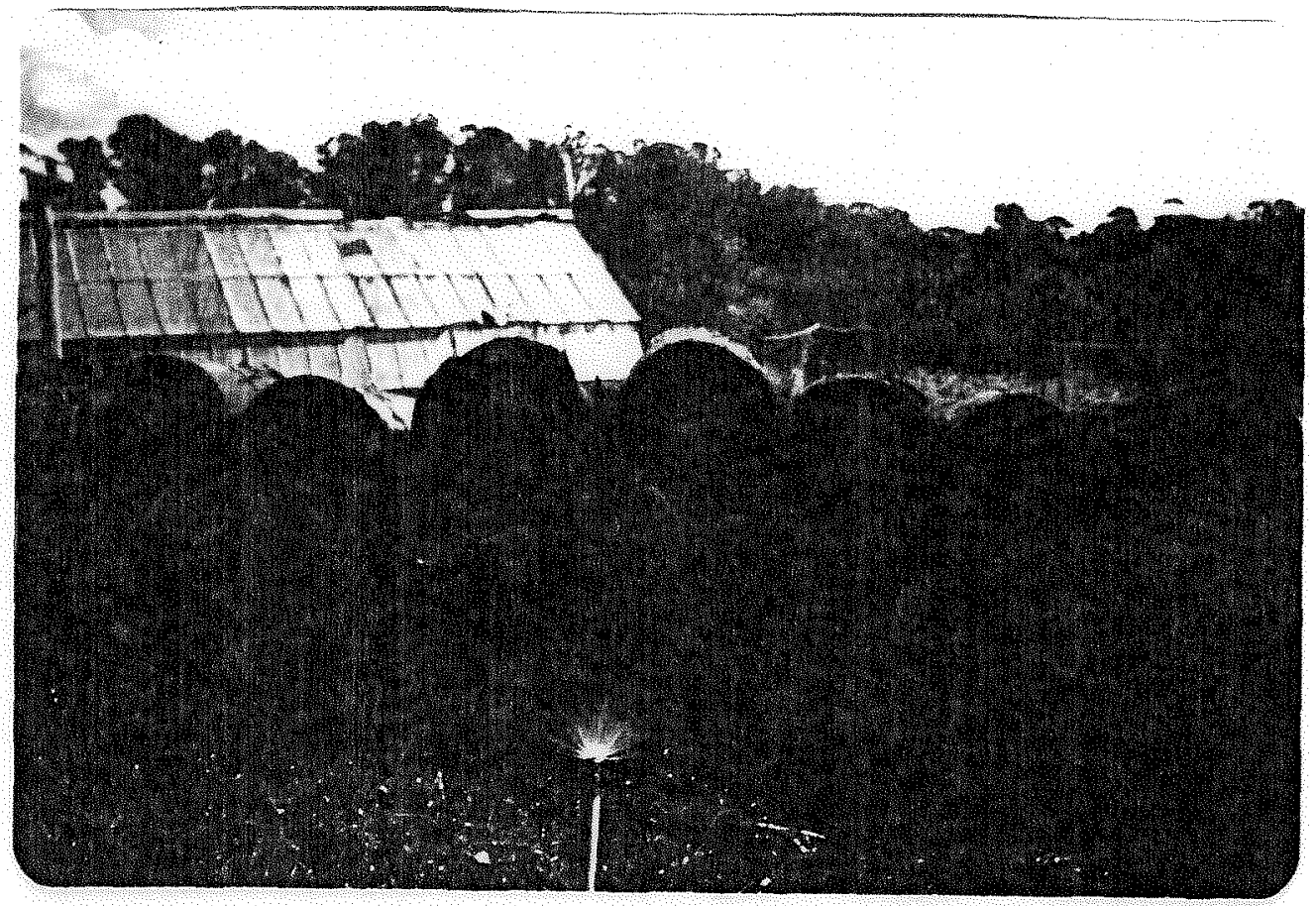

FIGURA 9. Armazenamento das toras sob aspersão d'água. (Armazenamento II). 
A combinação entre as variáveis totalizou tratamentos com 2 repetições, analisados num delineamento in teiramente ao acaso em um esquema fatorial $2 \times 4 \times 3 \times 2$.

\subsection{Aval iação das rachaduras de topo}

Concluidos os tempos de armazenamento, foram retiradas ao acaso duas toras de cada tratamento. O comprimento das mesmas foi reduzido para $1 \mathrm{~m}$ pela retirada de 40 cm em cada extremidade. Nas novas faces de topos das toras efetuaram-se as medições das rachaduras.

A determinação das rachaduras constitui-se inicialmente da projeção nas faces das toras de três circulos concêntricos, com auxilio de lápis de cera, afastados entre si à uma distância de aproximadamente $1 / 3$ do raio médio da face em avaliação, conforme Figura 10.

Em sequência, localizou-se a rachadura princí pal da face laquela que passa pela medula, de um lado para outro) e com auxilio de uma régua com precisão de 1,0 mm mediu-se a maior abertura da rachadura dentro de cada seção, 


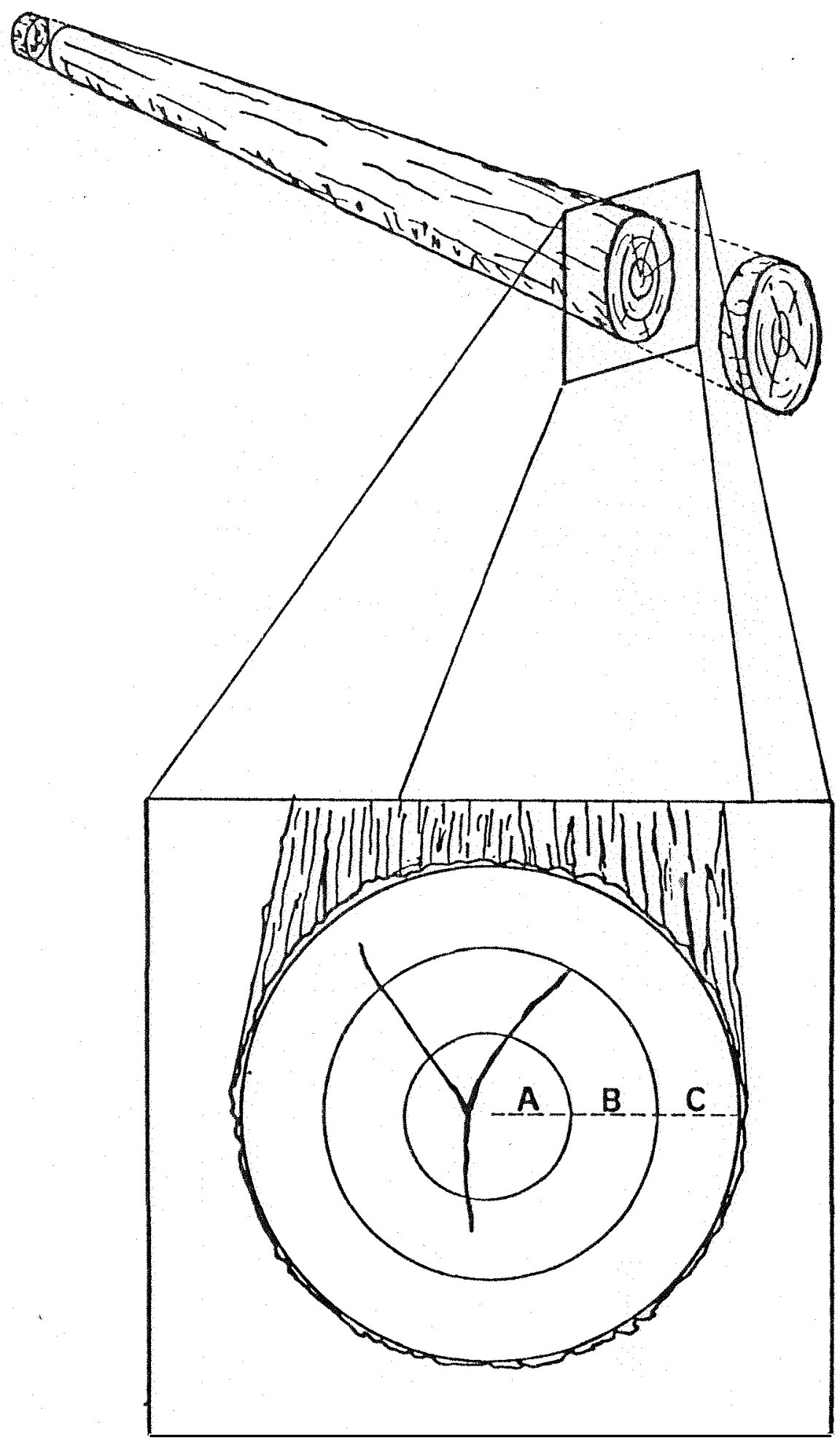

.43.

FIGURA 10. Projeção do corte de topo de uma tora onde foram efetuadas as avaliações de rachaduras. Observa-se no detalhe as secções $A, B$ e $C$. 
atribuindo-se os seguintes pesos: centena para C, dezena para $B$ e unidade para A.

A atribuição de diferentes pesos pela localização das rachaduras na face da tora foi devido a importância de cada seção no processo de laminação por desenrolamen to. Para melhor entendimento temos o seguinte exemplo: na seção C, o valor da abertura foi $3 \mathrm{~mm}$, na B $2 \mathrm{~mm}$ e na $A$ $\mathrm{mm}$, logo o valor para este topo foi 321, que somado ao valor do outro topo da mesma tora (221), resultou em um indice que è representado pela média dos valores dos topos da tora em exame (271)

3.4. Determinação da densidade bāsica das toras de Eucalyptus grandis

Para determinar a densidade básica das toras, utilizaram-se discos com 2,5 cm de espessura, retirados de doze toras escolhidas ao acaso entre as dezesseis pertencentes a segunda fase de avaliação do tratamento armazenamento ao ar (Armazenamento I).

Os discos, após saturados em água, foram divididos em quatro cunhas e a densidade básica foi determinada para cada uma pelo método da balança hidrostática (Norma ABCP $M-14-70)$. 
3.5. Análise estatística

Para se obter uma distribuição mais próxima da curva normal, os dados originais foram transformados para $\log (x)$. Decidiu-se aplicar essa transformação por ser a que resultou, dentre as transformações testadas, no melhor ajuste.

As variações entre tratamentos, foram analisa das através do delineamento inteiramente ao acaso num esquema fatorial $2 \times 4 \times 3 \times 2$ com 2 repetições (Tabela 3 ). A com paração entre tratamentos foi efetuada aplicando-se o teste F.

Para comparação entre médias dos tratamentos, foi usado o teste Tukey, aplicado aos niveis de $1 \%$ e $5 \%$ de probabilidade. Os dados foram analisados com auxilio dos computadores da Empresa Brasileira de Pesquisa AgropecuáriaEMBRAPA, pelo sistema "STATISTICAL ANALYSIS SYSTEM". 
TABELÀ 3. Quadro de análise da variância para o delineamento inteiramente casualisado num esquema fatorial $2 \mathrm{x}$ $4 \times 3 \times 2$, com 2 repetições

Fonte de variação

Tratamento (C)

Tratamento (P)

Tratamento (A)

Tratamento ( $\mathrm{T})$

Interação C x P

Interação C x A

Interação C $\times$ T

Interação $\mathrm{P} \times \mathrm{A}$

Interação $\mathrm{P} \times \mathrm{T}$

Interaç̃o A $\times$ T

Interaçäo $\mathrm{C} \times \stackrel{*}{\mathrm{P}} \times \mathrm{A}$

Interação $\mathrm{C} \times \mathrm{P} \times \mathrm{T}$

Interação $\mathrm{P} \times \mathrm{A} \times \mathrm{T}$

Tratamentos

Resíduo

Total
G. L .

$$
\begin{aligned}
& c-1 \\
& p-1 \\
& a-1 \\
& t-1
\end{aligned}
$$

$(c-1)(p-1)$

$(c-1)(a-1)$

$(c-1)(t-1)$

$(c-1)(a-1)$

$(c-1)(t-1)$

$(c-1)(t-1)$

$(c-1)(p-1)(a-1)$

$(c-1)(p-1)(t-1)$

$(p-1)(a-1)(t-1)$ $t-1$

$(n-1)(t-1)$ 
3.6. Produção das lâminas

Das trinta e duas toras do tratamento de imer são total em água (Armazenamento I) foram selecionadas vinte que apresentaram os menores indices de rachaduras, e utiliza das na produção de lâminas por desenrolamento.

Logo após as avaliações das rachaduras de topo, as toras foram aquecidas por imersão em água à temperatụ ra em torno de $70^{\circ} \mathrm{C}$, seguindo-se as recomendações de LUTZ (1974) .

As toras foram laminadas em um torno THOMS \& BENATO; modelo LHT-14, pertencente ao setor de Painéis a Base de Madeira, do Departamento de Ciências Florestais da Escola Superior de Agricultura "Luiz de Queiroz" da Universida de de São Paulo (DCF-ESALQ/USP). O torno foi regulado de acor do com as indicações de FEIHL e GODIN (1970) para lâminas de $2 \mathrm{~mm}$ de espessura (Tabela 4).

O rendimento (R) foi estimado pela relação en tre a conversão observada (CO) e a conversão teórica (CT), expresso percentualmente

$$
R=(\mathrm{CO} / \mathrm{CT}) \cdot 100
$$

sendo:

$\mathrm{CO}=$ conversão observada $=$ valor real do comprimento da lâm $\underline{i}$ na em $m$, obtida no desenrolamento da tora; 
$\mathrm{CT}=$ conversão teórica $=$ valor teórico do comprimento da lâmina, em $m$, para uma determinada espessura, produzida a partir do diâmetro médio (Dm) da tora até o diâmetro do rolete residual (Dr), calculado através da fórmula:

$$
C T=C L / 100=\frac{\frac{\pi}{4}\left(D_{m}^{2}-D^{2}\right)}{\text { e.. } 100}
$$

onde:

$\mathrm{CL}=$ comprimento da lâmina, em $\mathrm{cm}$

Dm = diâmetro maior, em cm

$\mathrm{Dr}=$ diâmetro menor, em $\mathrm{cm}$

e = espessura da lâmina, em $\mathrm{cm}$.

TABELA 4. Regulagem do torno para produção de lâminas com 2 mm de espessura.

Ângulo de afiação da faca

$20^{\circ} 00^{\prime}$

Ângulo da faca $90^{\circ} 30^{\prime}$ a $89^{\circ} 30^{\prime}$

Ångulo de compressão da contra-faca $15^{\circ} 00^{\prime}$ Abertura horizontal $1,85 \mathrm{~mm}$ Abertura vertical $0,5 \mathrm{~mm}$ 
Adicionalmente efetuou-se a classificação visual das lâminas, através de amostragem da seguinte forma:

- no sentido do comprimento da lâmina foi efetuada a amostra gem de $1 \mathrm{~m}^{2}$, a uma distância de aproximadamente $2,5 \mathrm{~m}$ entre amostras, quantificando-se número de nós por $\mathrm{m}^{2}$ e a porcentagem de lâminas com e sem nós. 


\section{RESULTADOS E DISCUSSÃO}

Considerando-se a importāncia dos parāmetros determinados neste trabalho, torna-se necessário discuti-los individualmente.

4.1. DENSIDADE BÁSICA MÉdIA DA MADEIRA DAS TORAS DE EUCALYPTUS GRANDIS

Os resultados da determinação da densidade bạ sica são apresentados na Tabela 5. Comparando-se esses valo res com resultados de estudos realizados no Brasil e na Austrália, por FERREIRA (1973), CARPIM e BARRICHELO (1984), BARRICHELO E NARAYOSHI (1984) e HALL e CHIPPENDALEI respectivamente, pode-se afirmar que a densidade básica do 
material em estudo se encontra de acordo com os valores encontrados para a espécie.

TABELA 5. Densidade básica $\left(\mathrm{g} / \mathrm{cm}^{3}\right)$, das cunhas, e valores mê dios dos discos e das toras.

\begin{tabular}{|c|c|c|c|c|c|}
\hline \multirow[t]{2}{*}{ No da toras } & \multicolumn{4}{|c|}{ Cunha } & \multirow{2}{*}{$\begin{array}{l}\text { Média } \\
\text { (disco) }\end{array}$} \\
\hline & I & II & III & IV & \\
\hline 1 & 0,52 & 0,56 & 0,54 & 0,54 & 0,54 \\
\hline 2 & 0,54 & 0,57 & 0,55 & 0,56 & 0,55 \\
\hline 3 & 0,50 & 0,49 & 0,49 & 0,48 & 0,49 \\
\hline 4 & 0,55 & 0,54 & 0,55 & 0,55 & 0,55 \\
\hline 5 & 0,54 & 0,56 & 0,54 & 0,53 & 0,54 \\
\hline 6 & 0,48 & 0,46 & 0,48 & 0,48 & 0,47 \\
\hline 7 & 0,50 & 0,50 & 0,51 & 0,52 & 0,51 \\
\hline 8 & 0,52 & 0,52 & 0,49 & 0,48 & 0,50 \\
\hline 9 & 0,59 & 0,59 & 0,59 & 0,61 & 0,59 \\
\hline 10 & 0,50 & 0,48 & 0,48 & 0,50 & 0,49 \\
\hline 11 & 0,58 & 0,58 & 0,56 & 0,56 & 0,57 \\
\hline 12 & 0,50 & 0,49 & 0,49 & 0,51 & 0,50 \\
\hline Média (das $t$ & oras) & & & & 0,52 \\
\hline Amplitude de & vari & & & & $47-0,59$ \\
\hline Coeficiente & de va & (CV) & & & $7,0 \%$ \\
\hline
\end{tabular}


Segundo trabalho publicado pela IUFRO (1973), as melhores lâminas desenroladas de madeira são, geralmente, aquelas produzidas de espécies com peso especifico moderado, variando entre $0,4 \mathrm{~g} / \mathrm{cm}^{3}$ a $0,6 \mathrm{~g} / \mathrm{cm}^{3}$.

Considerando-se as informações de literatura, e os resultados da Tabela 5, pode-se inferir que o valor encontrado para a densidade básica é normal para a espécie e a variação entre as toras pode ser considerada baixa. Da mesma forma, verifica-se que a madeira de Eucalyptus grandis apre senta densidade básica dentro da amplitude considerada favorável para a produção de lâminas e compensados.

4.2. Aval iaçãa das rachaduras de topo

Concluidos os períodos de armazenamento (dois e doze meses), foram avaliadas as rachaduras nos topos das toras. Os resultados são apresentados nas Tabelas 6, para os dados originais, e 7 para os dados transformados em log (x) . Cada valor representa a média de duas toras por tratamento. 


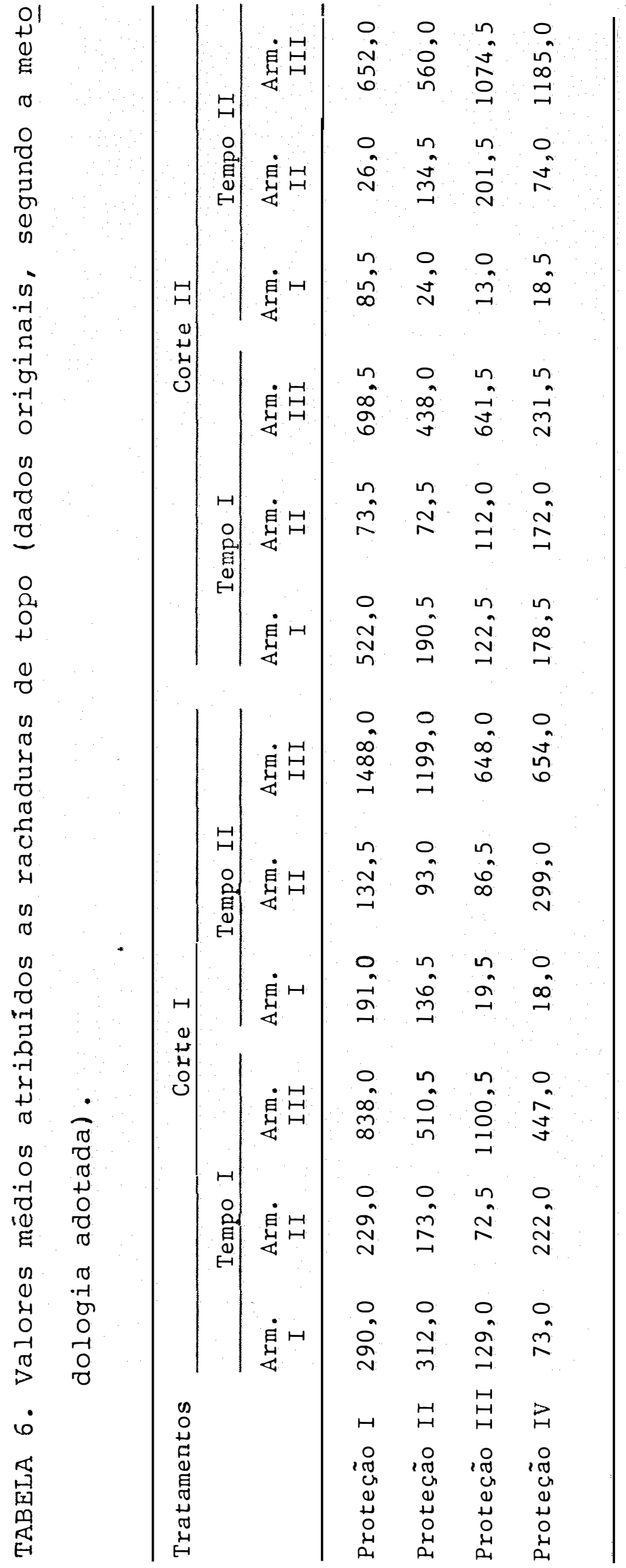




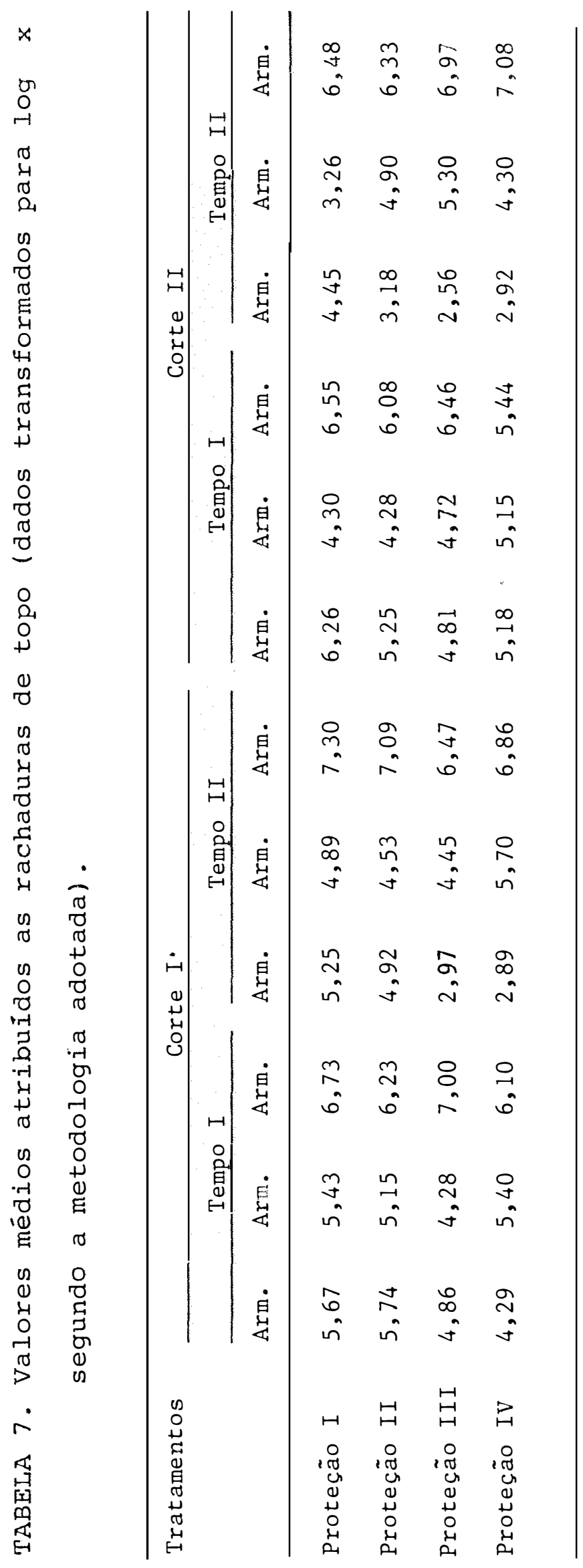


Nas Tabelas 8 a 13 são apresentados os quadros de dupla entrada, com os dados transformados, visando facilitar a análise e a comparação das interações entre tratamentos. Os resultados da análise de variância, aplicada aos valores da Tabela 7, são apresentados na Tabela 14 .

TABELA 8. Médias das interações de corte e proteção, representadas por 12 repetições.

\begin{tabular}{lcc}
\hline Tratamento & Corte I & Corte II \\
\hline Proteção I & 5,68 & 4,87 \\
Proteção II & 5,52 & 4,89 \\
Proteção III & 4,75 & 4,59 \\
Proteção IV & 5,12 & 4,77 \\
\hline
\end{tabular}

TABELA 9. Médias das interações de corte e tempo, rẹresenta das por 24 repetições.

\begin{tabular}{lcc}
\hline Tratamento & Tempo I & Tempo II \\
\hline Corte I & 5,42 & 5,11 \\
Corte II & 4,99 & 4,57 \\
\hline
\end{tabular}


TABELA 10. Médias das interações de corte e armazenamento, re presentadas por 16 repetições.

\begin{tabular}{lcc}
\hline Tratamento & Corte I & Corte II \\
\hline Armazenamento I & 4,37 & 4,20 \\
Armazenamento II & 4,76 & 3,94 \\
Armazenamento III & 6,67 & 6,20 \\
\hline
\end{tabular}

TABELA 11. Médias das interações de proteção e armazenamenta representadas por 8 repetições.

\begin{tabular}{lccc}
\hline Tratamento & $\begin{array}{c}\text { Armazenamento } \\
\text { I }\end{array}$ & $\begin{array}{c}\text { Armazenamento } \\
\text { II }\end{array}$ & $\begin{array}{c}\text { Armazenamento } \\
\text { III }\end{array}$ \\
\hline Proteção I & 5,14 & 4,02 & 6,65 \\
Proteção II & 4,72 & 4,59 & 6,30 \\
Proteção III & 3,56 & 3,78 & 6,67 \\
Proteção IV & 3,71 & 5,00 & 6,11 \\
\hline
\end{tabular}


TABELA 12. Médias das interações de armazenamento e tempo, re presentadas por 16 repetições.

Tratamento

Armazenamento I

Armazenamento II

Armazenamento III
Tempo I

5,07

4,41

6,41
Tempo II 3,50

4,29

6,53

TABELA 13. Médias das interações de proteção e tempo, representadas por 12 repetições.

\begin{tabular}{lcc}
\hline Tratamento & Tempo I & Tempo II \\
\hline Proteção I & 5,74 & 4,81 \\
Proteção II & 5,31 & 5,10 \\
Proteção III & 4,72 & 4,61 \\
Proteção IV & 5,05 & 4,83 \\
\hline
\end{tabular}


TABELA 14. Resultados de análise da variância aplicada aos resultados da Tabela 7 (valoresoriginais previamente transformados para $\log \mathrm{x}$ ).

\begin{tabular}{lrrrrc}
\hline C.V. & G.L. & S.Q. & Q.M. & F & Prob. \\
\hline Corte (C) & 1 & 5,66 & 5,66 & $4,76 *$ & $(0,033)$ \\
Proteção (P) & 3 & 5,44 & 1,81 & $1,52 \mathrm{~ns}$ & $(0,216)$ \\
Armazenamento (A) & 2 & 95,78 & 47,89 & $40,24 * *$ & $(0,001)$ \\
Tempo (T) & 1 & 3,24 & 3,24 & $2,72 \mathrm{~ns}$ & $(0,103)$ \\
Corte x Proteção & 3 & 1,50 & 0,50 & $0,42 \mathrm{~ns}$ & $(0,742)$ \\
Corte x Armaz. & 2 & 1,72 & 0,86 & $0,72 \mathrm{~ns}$ & $(0,489)$ \\
Corte x Tempo & 1 & 0,09 & 0,09 & $0,07 \mathrm{~ns}$ & $(0,787)$ \\
Proteção x Armaz & 6 & 17,95 & 2,99 & $2,51 *$ & $(0,030)$ \\
Proteção x Tempo & 3 & 2,56 & 0,85 & $0,71 \mathrm{~ns}$ & $(0,548)$ \\
Armaz. x Tempo & 2 & 19,35 & 9,68 & $8,13 * *$ & $(0,008)$ \\
C x P x A & 6 & 5,27 & 0,88 & $0,74 \mathrm{~ns}$ & $(0,621)$ \\
C x P x T & 3 & 1,93 & 0,64 & $0,54 \mathrm{~ns}$ & $(0,660)$ \\
C x A x T & 2 & 1,95 & 0,98 & $0,82 \mathrm{~ns}$ & $(0,445)$ \\
\hline Tratamentos & 35 & 162,45 & 4,64 & $3,90 * *$ & \\
Resíduo & 60 & 71,41 & 1,19 & & \\
\hline Total & 95 & 233,86 & & & \\
\hline
\end{tabular}

Coeficiente de Variação $(\mathrm{CV})=21,7 \%$ 
A análise da variância acusou significâncias pelo teste $F$, aos niveis de $1 \%$ e 5\% de probabilidade, para os tratamentos armazenamento e corte, respectivamente. Já os tratamentos proteção e tempo, quando analisados individual mente não apresentaram significância, porém quando analisados dentro dos diferentes tratamentos de armazenamento (I, II e III), as interações foram significativas aos niveis de 1\% para o tempo e 5\% para proteção. Nas demais interações o teste $F$ não apresentou significância.

Com a aplicação do teste de Tukey, observou-se que o corte industrial apresentou maior valor para as rachaduras de topo, quando comparado ao corte com anelamento (Tabela 15) .

TABELA 15. Testè de Tukey aplicado aos tratamentos de corte.

\begin{tabular}{lcccc}
\hline Tratamento & $\begin{array}{c}\text { No de } \\
\text { repetições }\end{array}$ & \multicolumn{2}{c}{ Médias } & Tukey \\
\cline { 3 - 5 } & 48 & 192,48 & 5,26 & 58 \\
Corte I & 48 & 119,10 & 4,78 & a \\
Corte II & & & $\mathrm{b}$ \\
\hline
\end{tabular}

O efeito do anelamento (Corte II), no controle das rachaduras de topo originadas pelas tensões internas 
de crescimento, foi mencionado nos trabalhos de BARNACLE e GOTTSTEIN (1968), GIORDANO e CURRO (1972) e MALAN (1979). Em um trabalho semelhante VAN WYK (1978), na Âfrica do Sul, mos trou que havia um retardamento na manifestação das rachaduras em toras de Eucalyptus spp, quando era feito um anelamen to com uma profundidade variando entre 2,5 a $4,0 \mathrm{~cm}$ à uma distância de $1 / 3$ do diāmetro do corte transversal. CONRADIE (1980), em seus estudos com Eucalyptus grandis, encontrou uma alta, positiva e significativa interação entre a profundidade do anelamento e a distância do corte transversal com a intensidade das rachaduras.

O efeito do anelamento nas tensões de crescimento pode ser melhor entendido analisando-se o que ocorre com a árvore por ocasião do corte.

Quando uma árvore em pé, que contém um alto nível de tensão longitudinal de crescimento em equilíbrio, é cortada transversalmente, a face do corte apresenta algumas deformações; ou seja, a parte externa próxima à casca,que es taria inicialmente sob tensão de tração, sofre um ligeiro en colhimento e a parte central próxima a medula, que estava sob tração de compressão, um alongamento. A superficie da face do corte transversal que deveria estar plana, toma forma de uma calota e, consequentemente, a superficie do corte transversal aumenta sua área até o máximo da sua resistência à tração perpendicular aos raios, iniciando-se o apareci 
mento de uma fenda principal, ao longo do raio, passando pela medula. Dependendo da espécie, outras rachaduras secundá rias poderão aparecer.

Quando é utilizada a técnica de anelamento an tes do corte transversal ocorre a eliminação de parte das tensões próximas a casca, diminuindo-se desta maneira a ação das forças responsáveis pela formação da calota na face tran versal após o corte. A liberação de parte das tensões inter nas de crescimento é limitada na extensão entre o anelamento e a face de corte.

Se as avaliações das rachaduras fossem realizadas na face original do corte transversal, os valores para rachaduras de topo no corte com anelamento tenderiam à ZERO. Mas como a finalidade deste estudo não era tão somente a eli minação das rachaduras de topo das toras, mas também a diminuição das tensões internas de crescimento, procedeu-se, após os periodos de armazenamento, reduções nos comprimentos das toras para um metro. Com isso, a face que sofreu avalia ção ficou fora da extensão que estava neutralizada pelo ane lamento. Esse procedimento foi repetido para os dois tipos de corte (I e II).

Portanto, pode-se afirmar em função dos resul tados observados, que o anelamento diminuiu significa tivamente as tensões internas de crescimento residuais nas to ras estudadas, o que permite aceitar a provável possibilida- 
de da utilização da madeira de Eucalyptus grandis na produção de lâminas desenroladas e na produção de madeira serrada, a partir das toras que receberam o anelamento antes do corte transversal.

Para os tratamentos de armazenamento, a análi se da variância acusou, através do teste $F$, diferença significativa ao nivel de $1 \%$ de probabilidade. O resultado para o armazenamento III (ao ar) mostrou diferença significativa pelo teste de Tukey, quando comparado com os armazenamentos I e II (aspersão e imersão), conforme pode ser verificado na Tabela 16 .

TABELA 16. Teste de Tukey aplicado aos tratamentos de armaze namentos.

\begin{tabular}{lcccc}
\hline Tratamento & $\begin{array}{c}\text { No de } \\
\text { repetições }\end{array}$ & Tukey \\
\cline { 5 - 5 } & & Originais & Transformadas & 58 \\
\hline $\begin{array}{c}\text { Armazena- } \\
\text { mento I }\end{array}$ & 32 & 72,24 & 4,28 & a \\
$\begin{array}{c}\text { Armazena- } \\
\text { mento II }\end{array}$ & 32 & 77,48 & 4,35 & $\mathrm{a}$ \\
$\begin{array}{c}\text { Armazena- } \\
\text { mento III }\end{array}$ & 32 & 620,17 & 6,43 & $\mathrm{~b}$ \\
\hline
\end{tabular}


Os resultados observados são coerentes com as informações contidas em vários estudos existentes na literatura. DOBIE (1965), depois de fazer uma revisão sobre práti cas de armazenamento de toras, concluiu que a armazenagem das toras imersas em água produz a mais efetiva proteção tan to para rachadura de topo como para ataque de fungos e insetos, seguido pelo armazenamento sob aspersão d'água. Turnbull (1965), citado por CHAFE (1979), concluiu que toras imersas em água por vários anos são facilmente serradas sem apresentar empenamentos. NICHOLSON (1973a) não encontrou evo lução das rachaduras de topo das toras armazenadas por 300 dias, sob aspersão d'água.

A maior intensidade das rachaduras nas toras submetidas ao armazenamento III (ao ar), é, seguramente, um efeito da secagem das mesmas. Quando uma tora é armazenada ao ar, ou seja, exposta às condicões de ambiente e sem prote ção dos raios solares, ela imediatamente entre em processo de secagem. Como a movimentação da água na madeira é mais rápida no sentido longitudinal, os topos chegam, dentro de pouco tempo, a teores de umidade abaixo do ponto de saturação das fibras. Iniciam-se nesse momento as retrações das partes mais secas, e como a parte mais interna da tora ainda está com alto teor de umidade e não acompanha essa retração, surgem tensões internas que, tornando-se superior à resistên cia da madeira, provocam o aparecimento das rachaduras. Dependendo das condições do ambiente as toras expostas ao ar 
podem ser totalmente rachadas, chegando a ocorrer separação de peças das toras. Segundo Barnacle (1971) e Iman e Heikal (1972), citados por MALAN (1984), as tensões de secagem inte ragem com as tensões de crescimento para produzir rachaduras nos topos.

O armazenamento das toras imersas e sob asper são (armazenamentos I e II) não apresentaram diferenças significativas entre si, conforme Tabela 16, confirmando que os dois tratamentos levam a resultados semelhantes, ou seja, não permitem a secagem das partes externas das toras. Com isso não há formação das tensões ocasionadas pela secagem, as quais poderiam interagir com as tensões de crescimento e produzir ou induzir ao aumento das rachaduras de topo.

Os trabalhos existentes na literatura indicam de um modo geral, que o armazenamento das toras imersas em água apresenta resultados ligeiramente superiores àqueles do armazenamento sob aspersão d'água (DOBIE, 1965). No armazenamento das toras sob imersão d'água, se fez necessário a mu dança periódica da água do reservatório devido à exalação de odores desagradáveis e com isșo traz o risco de poluição ambiental. .

As interações proteção $x$ armazenamento e tempo $\mathrm{x}$ armazenamento, apresentaram, pelo teste $\mathrm{F}$, diferenças significativas aos niveis de $5 \%$ e $1 \%$ de probabilidade, respectivamente (Tabela 14). Para analisar o efeito dos tratamentos dentro dos armazenamentos, efetuou-se nova análise de 
variāncia, cujos resultados são apresentados na Tabela 17 .

$$
\text { Observou-se que no armazenamen- }
$$

to I, tanto as proteções como os tempos de armazenamento apresentaram diferenças significativas ao nivel de $1 \%$ de probabilidade.

Os resultados do teste de Tukey, para compara ção das médias (Tabela 18), indicam que dentro do armazenamento I (toras imersas em āgua), as proteções I (sem proteção) e II (cera) apresentaram diferença significativa para rachaduras em relação às proteções III (Gang Nail) e IV (Gang Nail e Cera) e seus valores foram superiores.

Uma vez que no armazenamento I as rachaduras de topo sō se manifestaram devido às tensões internas de crescimento, a proteção II no armazenamento I, tornou-se ine ficiente devido ser sua principal finalidade a de minimizar os efeitos de secagem, daí seu resultado não apresentar dife rença significativa quando comparado com o tratamento proteção I (testemunha).

Por outro lado, os tratamentos proteção III e IV, que tinham como finalidade a restrição das deformações originadas das tensões internas de crescimento, apresentaram uma boa eficiência, resultando em diferenças significativas quando comparadas com os tratamentos I e II. 
.66 .

芩

ט

ט)

(1)

足

(1)

0

ن)

मि

i)

O

02

+ E

芩

$+0$

年 ह

0

O 0

苗

ก)

ज +

(1)

$\begin{array}{lll}0 & + \\ 0 & 0\end{array}$

E

$\stackrel{1}{r}$

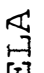

品

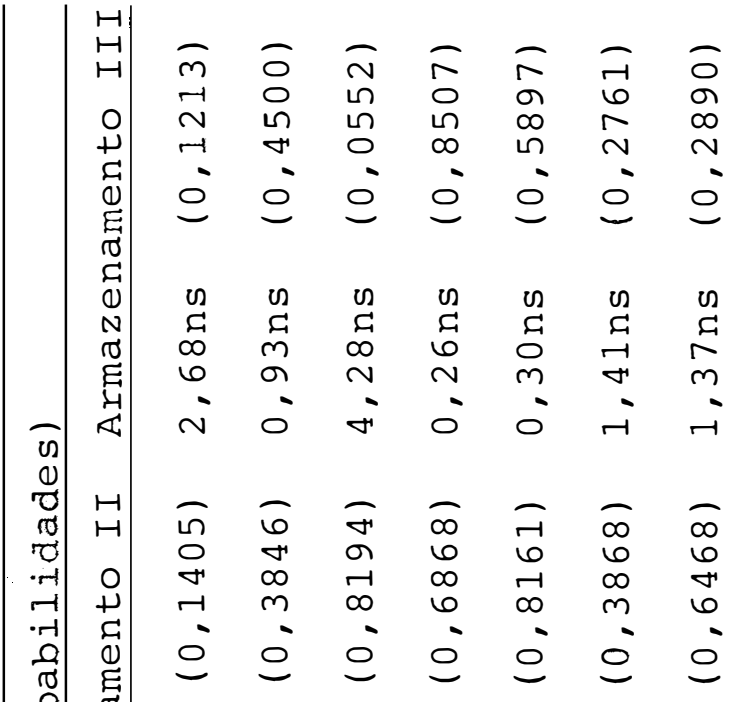

을

苨

我

$\stackrel{+}{+}$

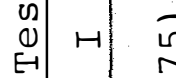

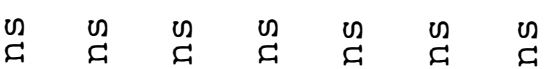

न $\infty$

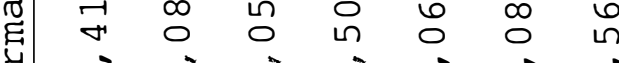

स

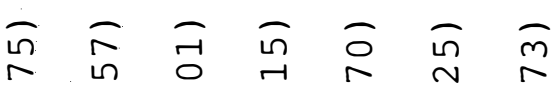

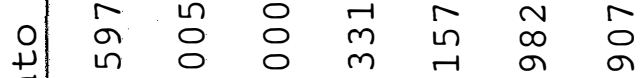

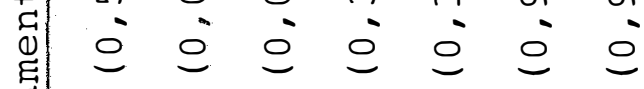

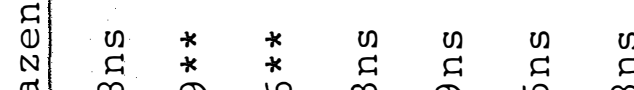

E. $\quad \begin{array}{lllllll}\infty & 0 & 0 & m & \sigma & 0 & \infty\end{array}$

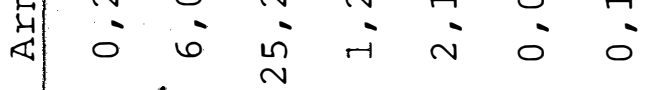

$$
\begin{array}{lllllll}
0 & 0 & n & 0
\end{array}
$$

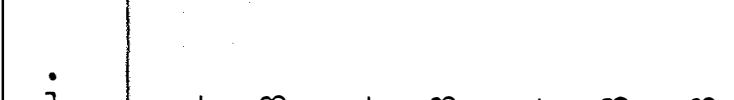

$\dot{\leftrightarrow}$

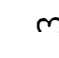

$m$

$m m$

ก

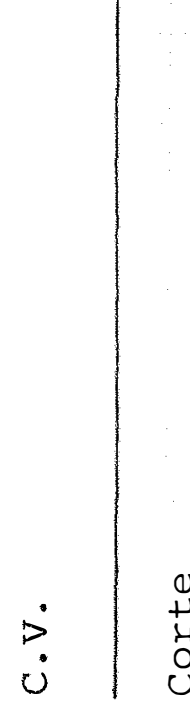

@

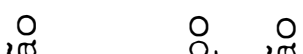

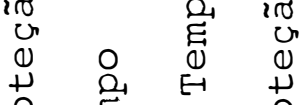

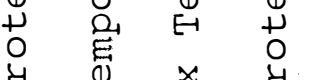

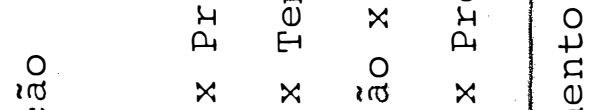

$\begin{array}{llllll}0 & x & x & 0 & x & 0 \\ 0 & 0 & 0 & 0\end{array}$

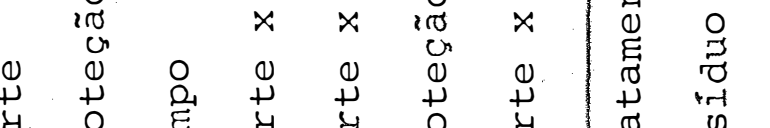

م)

$m$
m
0

$\begin{array}{ll}N & \\ 0 & N \\ 0 & N \\ 0 & N\end{array}$

감

$\underset{+1}{+1}$

范 
TABELA 18. Teste Tukey aplicado aos tratamentos proteções dentro do armazenamento I.

\begin{tabular}{|c|c|c|c|c|}
\hline \multirow[t]{3}{*}{ Tratamento } & \multirow{3}{*}{$\begin{array}{c}\mathrm{N} O \mathrm{de} \\
\text { repetições }\end{array}$} & \multicolumn{2}{|c|}{ Médias } & \multirow{3}{*}{$\begin{array}{c}\text { Tukey } \\
5 \%\end{array}$} \\
\hline & & Originais & Transformadas & \\
\hline & & \multicolumn{2}{|c|}{ Armazenamento I } & \\
\hline Proteção I & 8 & 170,71 & 5,14 & $\mathrm{a}$ \\
\hline Proteção II & 8 & 112,17 & 4,72 & $\mathrm{a}$ \\
\hline Proteção III & 8 & 35,16 & 3,56 & $\mathrm{~b}$ \\
\hline Proteção IV & 8 & 40,85 & 3,71 & $\mathrm{~b}$ \\
\hline
\end{tabular}

Na literatura foram encontrados alguns estudos que suportam os resultados em discussão. Meyer e Wegelin (1955), citados por MALAN (1984), concluiram que não hou ve redução nas tensões internas de crescimento quando do uso dos conectores anti-rachadura (Gang-Nail) e ganchos em forma de "S" ou "C", porém eles conservam as faces dos topos intactas até a secagem controlada ou outro tipo de reação que venha equilibrar as tensões internas de crescimento. Estudos realizados no Brasil por GERALDO e SODRE (1983), resultaram na indicação dos dispositivos anti-rachaduras tipo Gang-Nail para o controle das rachaduras de topo em postes de Eucalyptus saligna e seus hibridos.

Os resultados do teste Tukey para comparação 
das médias dos tempos I e II ( 2 e 12 meses) dentro do armaze namento I (imersão) indicam que o valor para rachaduras no tempo de armazenamento I foi superior ao valor para o tempo de armazenamento II, e o contraste entre as médias foi significativo (Tabela 19); de onde se pode concluir, que com 0 aumento de tempo de armazenamento das toras de Eucalyptus. grandis imersas em água, há uma diminuição das tensões de crescimento. Segundo CHAFE (1979) o alívio das tensões de crescimento é através da liberação de tensões que envolve uma acomodação das células ou componentes da parede celular. Baseando-se nestas informações e nos resultados encontrados, supõe-se que com o passar do tempo de armazenamento onde as toras não estejam sujeitas à secagem, ocorra um processo de fadiga ao nível de célula ou de parede celular e, com isso, diminuindo a elasticidade da madeira, tem-se a diminuição das tensões de crescimento.

TABELA 19. Teste de Tukey aplicados aos tempos de armazenamento I.

\begin{tabular}{lcccc}
\hline Tratamento & $\begin{array}{c}\text { No de } \\
\text { repetições }\end{array}$ & $\begin{array}{c}\text { Tukey } \\
5 \%\end{array}$ & \\
\cline { 3 - 4 } & & $\frac{2}{\text { Originais Trádias }}$ & \\
Tempo I & 16 & 159,17 & 5,07 & $\mathrm{a}$ \\
Tempo II & 16 & 33,11 & 3,50 & $\mathrm{~b}$ \\
\hline
\end{tabular}




\subsection{Produção de lâminas}

Os resultados observados na produção de lâminas verdes, a partir das vinte toras de Eucalyptus grandis, são apresentados na Tabela 20. Como era esperado, foi possị vel relacionar o comprimento de lâminas observado (CLO) com o diâmetro médio da tora (Dm), cuja reta de correlação pode ser visualizada na Figura 11.

Como pode se observar na Figura 11, existe uma variação considerável entre os comprimentos de lâminas estimado e o observado, causada principalmente pelas perdas no processo de laminação até atingir o arredondamento das to ras (DC). Esta variação é justificada basicamente pela morfologia das toras de Eucalyptus grandis, que refletem as caracteristicas fenotipicas das ārvores no povoamento como conicidade, excentricidade e presença de ramificações vigorosas e protuberâncias.

Dentre os diversos modelos testados, o da regressão linear simples foi que o melhor ajuste proporcionou entre o comprimento de lâmina observado (CLO) e o diâmetro médio (Dm) da tora, através da equação

$$
\text { CLO }=-41,244+2,097 \mathrm{Dm}
$$

com coeficiente de determinação:

$$
\left(x^{2}\right)=0,745 * *
$$


TABELA 20. Diâmetros médios das toras (Dm), cilindricos (DC), e do rolete final (Dr); comprimetnos de lâminas [estimado (CLE) e observado (CLO)] e rendimento em porcentagem [ (CLO/CLE) x 100].

\begin{tabular}{|c|c|c|c|c|c|c|}
\hline $\begin{array}{l}\text { No da } \\
\text { tora }\end{array}$ & $\begin{array}{c}\mathrm{Dm} \\
(\mathrm{cm})\end{array}$ & $\begin{array}{c}\text { DC } \\
(\mathrm{cm})\end{array}$ & $\begin{array}{c}\text { Dr } \\
(\mathrm{cm})\end{array}$ & $\begin{array}{l}\text { CLE } \\
(\mathrm{m})\end{array}$ & $\begin{array}{l}\text { CLO } \\
\text { (m) }\end{array}$ & $\begin{array}{c}\text { Rend. } \\
\left(\frac{q}{8}\right)\end{array}$ \\
\hline 01 & 30,5 & 25,5 & 10,0 & 32,60 & 21,52 & 66,00 \\
\hline 02 & 34,0 & 31,5 & 11,0 & 41,47 & 33,04 & 79,67 \\
\hline 03 & 37,5 & 34,0 & 11,0 & 51,30 & 39,68 & 77,35 \\
\hline 04 & 35,5 & 31,0 & 13,0 & 45,56 & 30,09 & 66,00 \\
\hline 05 & 32,0 & 28,0 & 10,0 & 36,28 & 27,28 & 75,20 \\
\hline 06 & 32,5 & 27,5 & 10,0 & 37,55 & 25,93 & 69,00 \\
\hline 07 & 34,5 & 32,0 & 12,0 & 42,81 & 34,77 & 81,20 \\
\hline 08 & 34,0 & 31,0 & 10,0 & 41,47 & 31,25 & 75,30 \\
\hline 09 & 30,5 & 27,5 & 10,0 & 32,60 & 25,99 & 79,70 \\
\hline 10 & 35,0 & 31,0 & 11,5 & 44,18 & 31,50 & 71,30 \\
\hline 11 & 33,0 & 28,5 & 10,0 & 38,84 & 27,37 & 70,50 \\
\hline 12 & 34,5 & 28,5 & 10,0 & 42,81 & 27,63 & 64,50 \\
\hline 13 & 31,5 & 29,0 & 16,0 & 35,04 & 23,20 & 60,20 \\
\hline 14 & 34,0 & 30,5 & 10,0 & 41,47 & 31,14 & 75,10 \\
\hline 15 & 33,5 & 33,0 & 17,5 & 40,14 & 30,07 & 74,90 \\
\hline 16 & 33,5 & 29,0 & 11,0 & 40,14 & 27,39 & 69,20 \\
\hline 17 & 33,5 & 30,0 & 10,0 & 40,14 & 27,78 & 69,20 \\
\hline 18 & 32,5 & 28,0 & 10,0 & 37,55 & 28,12 & 74,90 \\
\hline 19 & 31,5 & 28,5 & 15,5 & 35,04 & 23,45 & 66,90 \\
\hline 20 & 34,5 & 29,0 & 10,0 & 42,81 & 28,69 & 67,00 \\
\hline
\end{tabular}




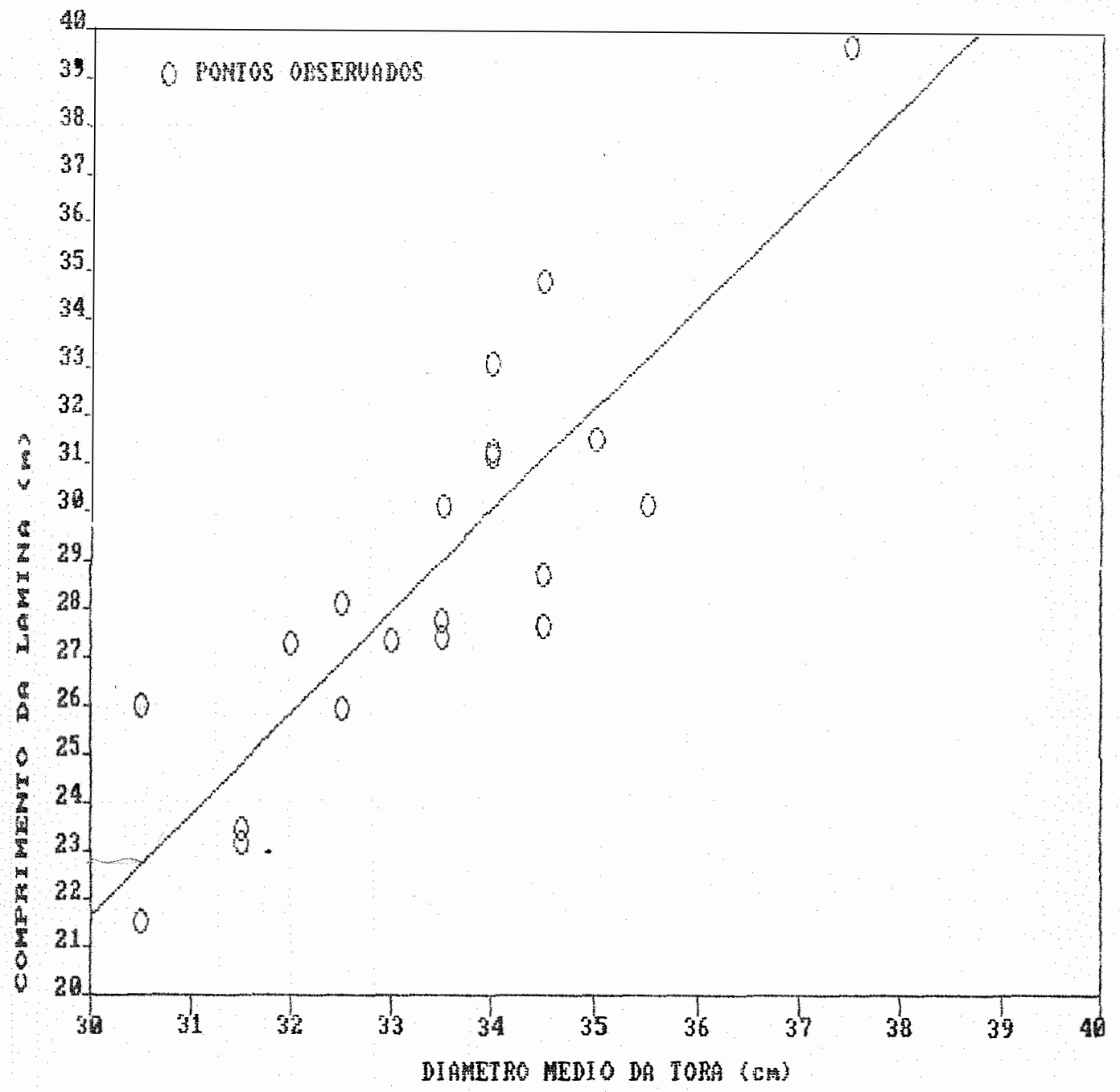

FIGURA 11. Representação gráfica da correlação entre os comprimentos de lâminas observados (CLO) em função dos diâmetros médios das toras desenroladas (Dm). 
Embora essa equação tenha sido estabelecida $\underline{\text { a }}$ penas com os resultados do presente trabalho, ela permitirá estimar, para o Eucalyptus grandis, 0 comprimento de lâminas de madeira com 2,0 mm de espessura conhecendo-se o diâmetro médio da tora.

Com os dados da Tabela 20 foi possivel elabo rar a equação de regressão linear, levando-se em consideração o comprimento de lâmina observado (CLO) e o comprimento de lâmina estimado (CLE) .

$$
\text { CLO }=-3,08614+0,797215 \text { (CLE) }
$$

com coeficiente $r^{2}=0,750 * *$

Da equação (2) temos que

$$
C L E=\frac{\Pi}{4}\left(\frac{D m^{2}-D r^{2}}{e}\right)
$$

Substituindo (5) em (4), obtem-se

$$
\begin{aligned}
& \text { CLO }=-3,08614+0,797215\left[\frac{\pi}{4}\left(-\frac{\mathrm{Dm}^{2}-\mathrm{Dr}^{2}}{\mathrm{e}}\right)\right] \\
& \mathrm{CLO}=-3,08614+0,62613\left(\frac{\mathrm{Dm}^{2}-\mathrm{Dr} \mathrm{r}^{2}}{\mathrm{e}}\right)
\end{aligned}
$$

com Dm, Dr e e com dimensões de [m].

$$
\text { Para utilizar a equação (7) com Dm e Dr em }
$$


[cm] e a espessura da lâmina (e) em [mm], tem-se a equação (8) .

$$
\text { CLO }=-3,08614+0,062613\left(\frac{\mathrm{Dm}^{2}-\mathrm{Dr}^{2}}{\mathrm{e}}\right)
$$

que da o resultado do comprimento de lâminas (CLO) em [m] .

Com base na equação (8) é possivel estimar a conversão de toras em lâminas conhecendo-se o diâmetro médio da tora e a espessura desejada para a lâmina, conforme é exemplificado na Tabela 21 e na Figura 12, para um rolete final com $10,0 \mathrm{~cm}$ de diâmetro.

4.4. QUALIDADE DAS LÂMINAS

As lâminas obtidas neste experimento (ilustra das na Figura 13) apresentaram as mesmas caracteristicas relatadas com JANKOWSKY e AGUIAR (1983), consideradas como razoavelmente lisas e fechadas. Essas caracteristicas de qualidade permitem afirmar a viabilidade da utilização na manufatura de painéis compensados.

O principal defeito em importância para a manufatura de compensados foi a alta incidência de nós mortos, conforme pode ser observado na Tabela 22 e Figuras 14 e 15. 
TABELA 21. Estimativa do comprimento de lâmina verde, em $m$, em função do diâmetro médio da tora (Dm) e espessura da lâmina (e) para um rolete final (Dr) com $10 \mathrm{~cm}$ de diâmetro.

\begin{tabular}{|c|c|c|c|c|c|}
\hline \multirow{2}{*}{\multicolumn{2}{|c|}{$\begin{array}{l}\text { Dm da tora } \\
(\mathrm{cm})\end{array}$}} & \multicolumn{4}{|c|}{ Espessura da lâmina (mm) } \\
\hline & & 1 & 2 & 3 & 4 \\
\hline & 30 & 47,00 & 21,96 & 13,61 & 9,45 \\
\hline & 31 & 50,82 & 23,87 & 14,88 & 10,39 \\
\hline & 32 & 54,77 & 25,84 & 15,20 & 11,38 \\
\hline & 33 & 58,84 & 27,88 & 17,55 & 12,39 \\
\hline & 34 & 63,03 & 29,97 & 18,95 & 13,44 \\
\hline & 35 & 67,35 & 32,13 & 20,39 & 14,52 \\
\hline & 36 & 71,80 & 34,36 & 21,88 & 15,63 \\
\hline & 37 & 76,37 & 36,64 & 23,40 & 16,78 \\
\hline & 38 & 81,06 & 38,99 & 24,96 & 17,95 \\
\hline & 39 & 85,89 & 41,40 & 26,57 & 19,16 \\
\hline & 40 & 90,83 & 43,87 & 28,22 & 20,39 \\
\hline
\end{tabular}




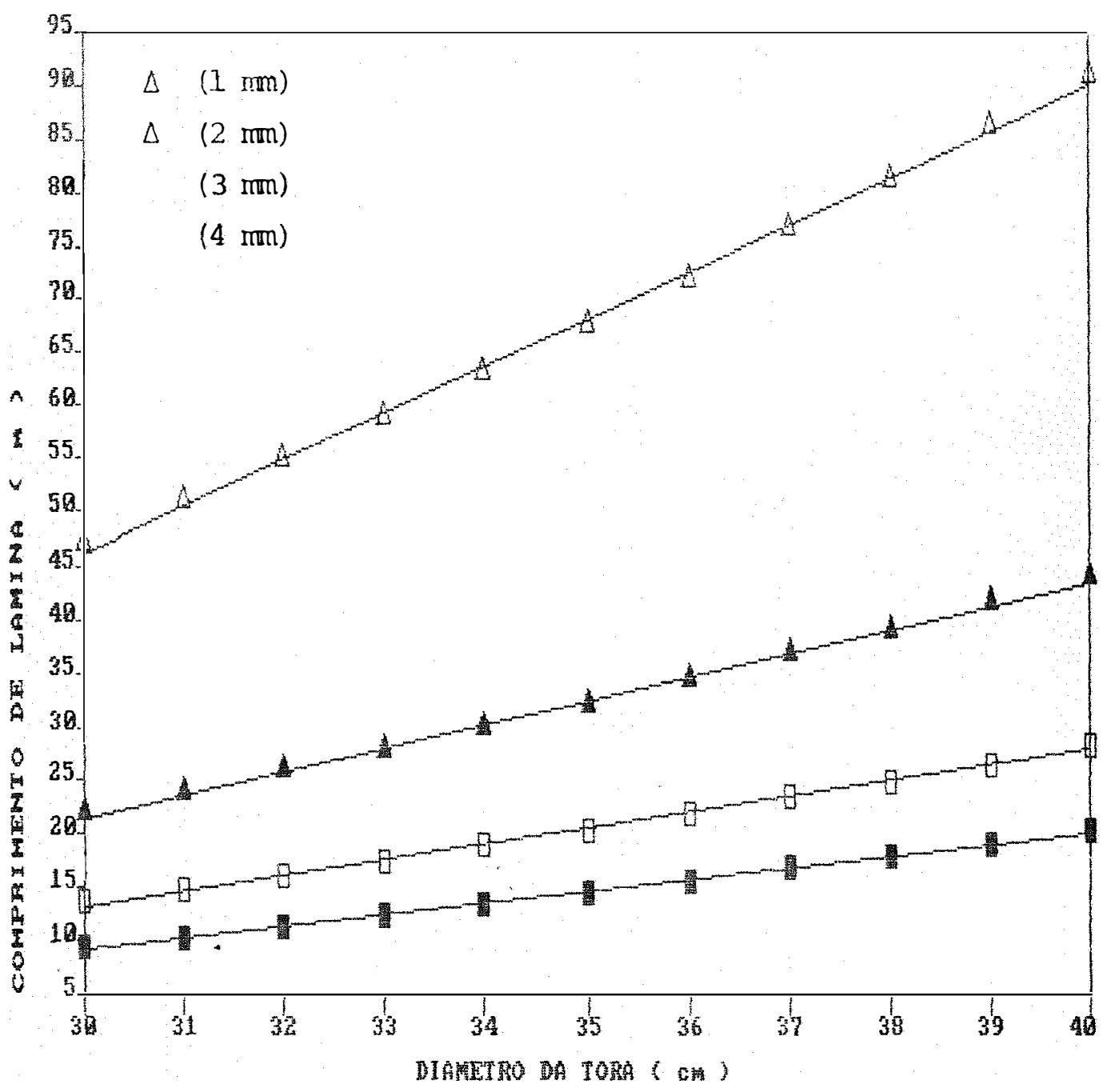

FIGURA 12: Conversão de toras em lâminas, conhecendo-se 0 diâmetro médio da tora e espessura desejada da lâa mina, para um rolete com $10 \mathrm{~cm}$ de diâmetro. 
.76 .

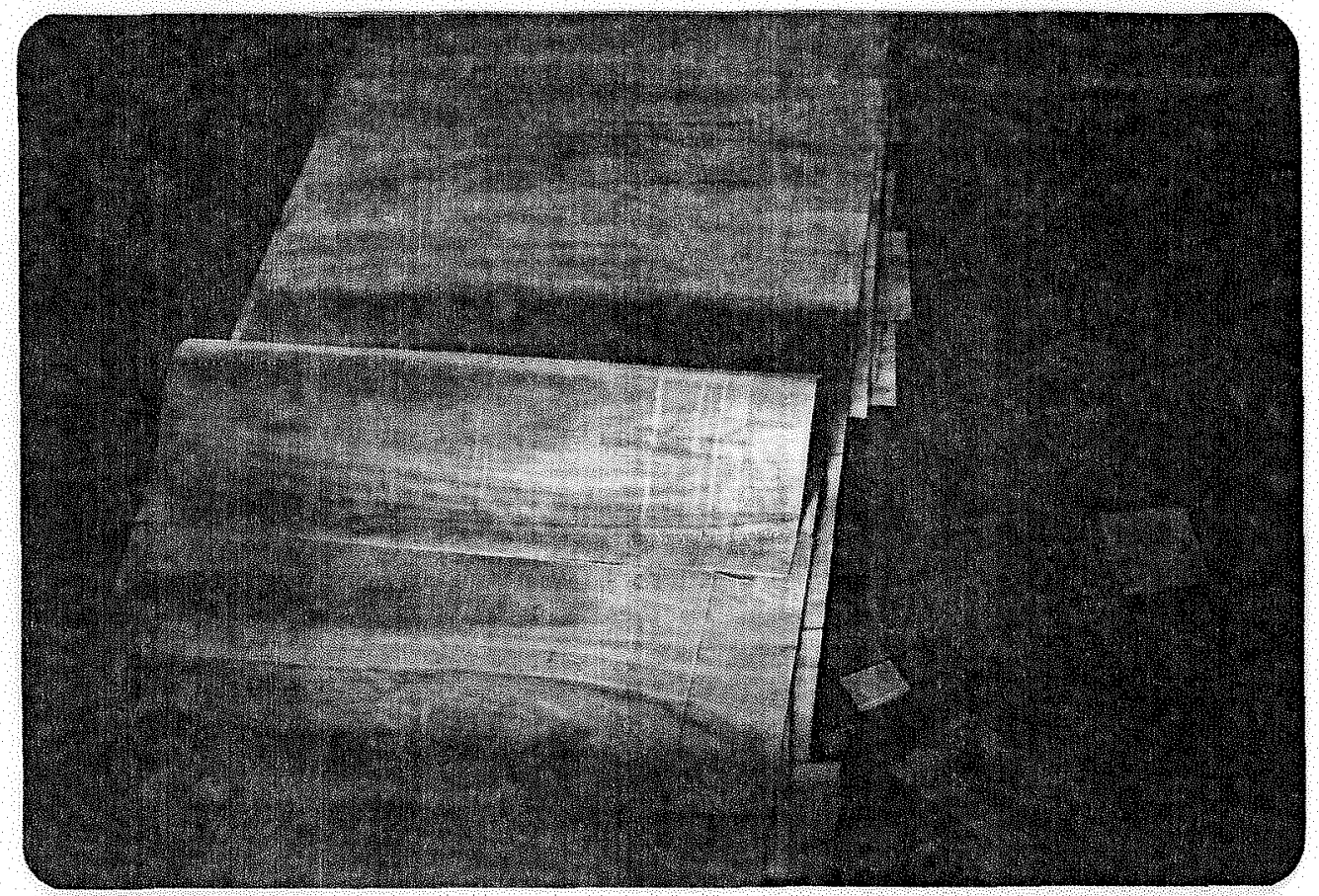

FIGURA 13. Lâmina produzida pelo método de desenrolamento em torno mecânico. 
TABELA 22. Porcentagem de lâminas com nós e amplitude da variação do número de nós por $\mathrm{m}^{2}$ de Iâmina.

No da tora
(\%) de Iâminas com nós
Intervalo

Mínimo - Máximo

\begin{tabular}{|c|c|c|c|c|}
\hline 1 & 100,0 & 2 & - & 28 \\
\hline 2 & 100,0 & 1 & - & 30 \\
\hline 3 & 100,0 & 3 & - & 27 \\
\hline 4 & 100,0 & 5 & - & 22 \\
\hline 5 & 100,0 & 2 & - & 34 \\
\hline 6 & 71,4 & 0 & - & 48 \\
\hline 7 & 100,0 & 2 & - & 30 \\
\hline 8 & 100,0 & 5 & - & 32 \\
\hline 9 & 85,7 & 0 & - & 47 \\
\hline 10 & 100,0 & 5 & - & 22 \\
\hline 11 & 55,5 & 0 & - & 41 \\
\hline 12 & 100,0 & 1 & - & 45 \\
\hline 13 & 100,0 & 6 & - & 16 \\
\hline 14 & 37,5 & 0 & - & 37 \\
\hline 15 & 28,6 & 0 & - & 6 \\
\hline 16 & 37,5 & 0 & - & 17 \\
\hline 17 & 75,0 & 0 & - & 37 \\
\hline 18 & 100,0 & 1 & - & 24 \\
\hline 19 & 0,0 & 0 & - & 0 \\
\hline 20 & 8,9 & 0 & - & 19 \\
\hline
\end{tabular}




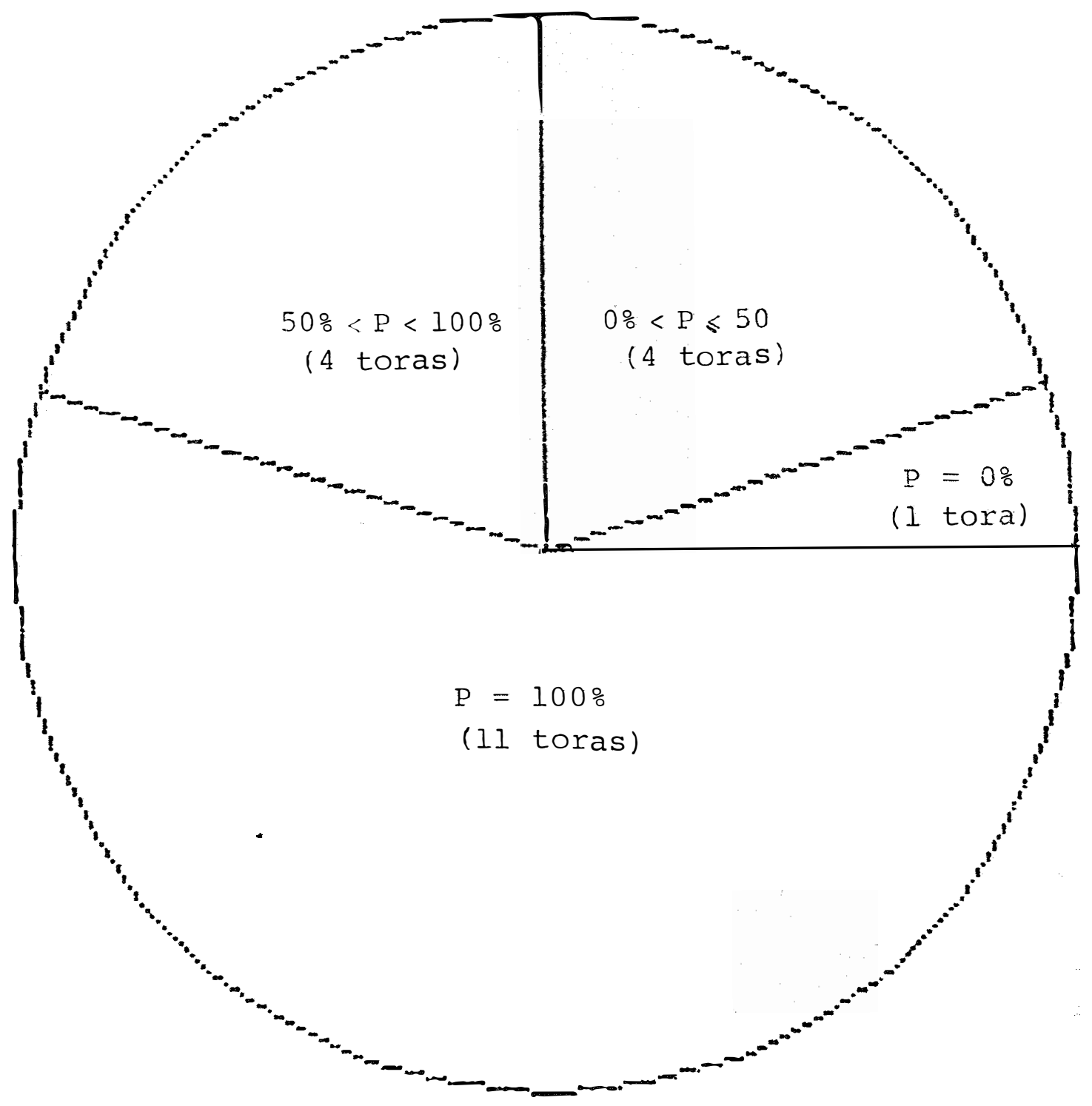

FIGURA 14. Distribuição da quantidade de toras em função da porcentagem (P) de lâminas com nös. 


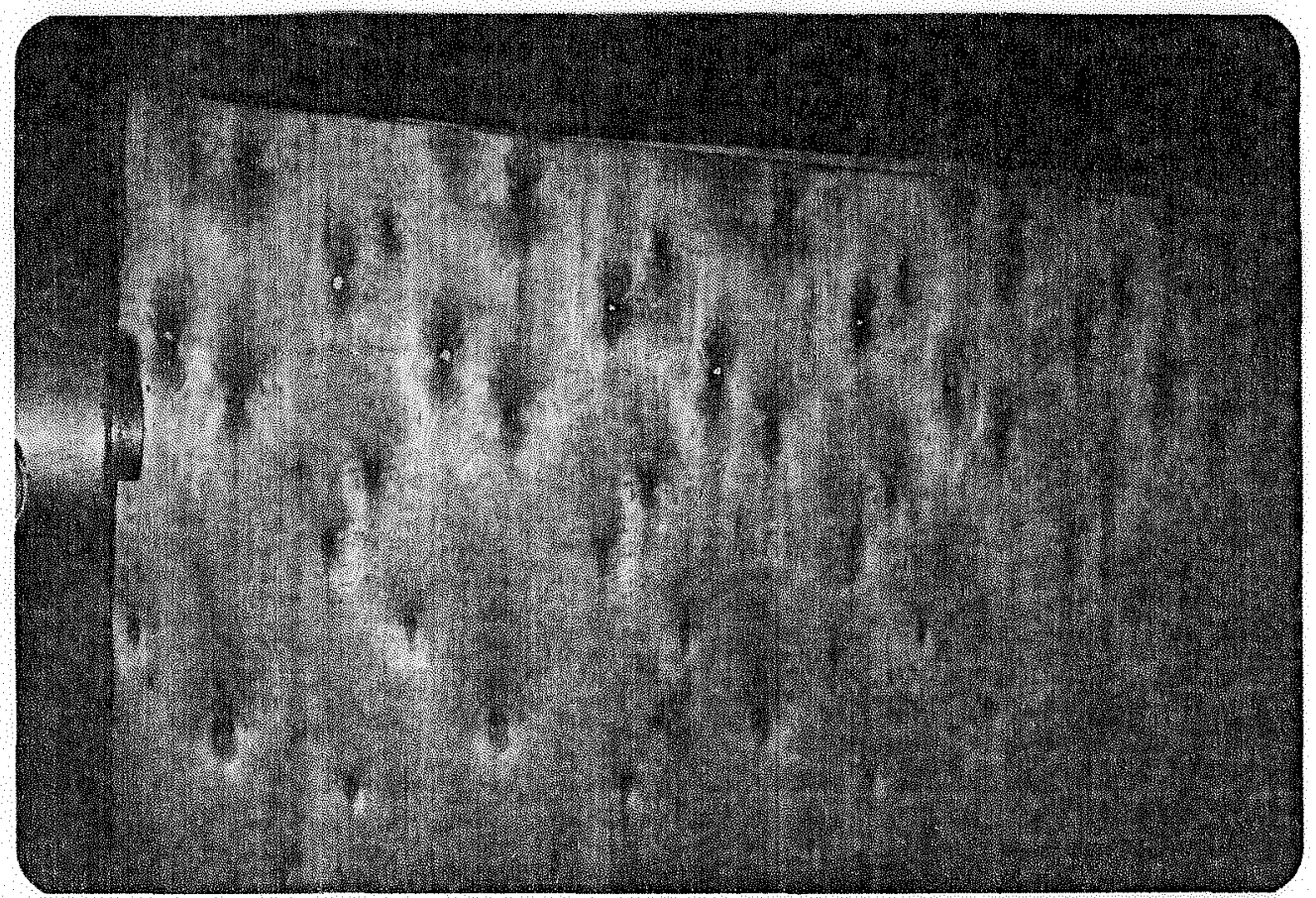

FIGURA 15. Lâmina produzida pelo método de desenrolamento, mostrando a alta incidência de nós mortos. 
A Tabela 22 e a Figura 14 mostram que dezenove das vinte toras laminadas apresentaram incidência de nös mortos, e que mais da metade do número de toras avaliadas tí nha suas lâminas totalmente perfuradas. Apenas de uma única tora foi possivel obter lâminas isentas de nós.

A grande incidência de nos é devida à presença dos tocos de galhos mortos, que permaneceram encrustados nos troncos das árvores (Figura 15).

Segundo MALAN (1984), as plantações de Eucalyptus grandis usualmente apresentam boa desrama natural,mas a liberação dos galhos somente acontece depois de dois a três anos após a secagem dos mesmos.

Os galhos inferiores do Eucalyptus grandis, devido à insuficiēncia da disponibilidade de luz, morrem cedo. Contudo, đependendo do espaçamento entre árvores, os ga lhos podem persistir no fuste durante o crescimento da árvore, encontrando-se posteriormente no tronco tocos de galhos mortos com mais de $10 \mathrm{~cm}$ de diâmetro, e que são facilmente atacados por fungos e insetos. Algumas vezes os Eucalyptus podem ter excelentes formas e apresentarem-se sadios, porém quando serrados aparecem os tocos de galhos mortos, veios de kino e outras imperfeições, as quais ocorrem devido a não exudação de resinas repelentes à água após a queda dos galhos, como ocorre com os Pinus (HILLIS, 1979). 
Segundo EDWARDS (1973), ésses danos podem ser reduzidos pelas técnicas silviculturais, e que muitas vezes devido aos altos custos, não são praticadas ou ocorrem com atrazo. SIMÕES et alii (1981) consideram que para a produção de celulose, energia e outros usos menos nobres da madei ra, a desrama natural é considerada suficiente.

Segundo os resultados apresentados neste trabalho e as classificações para lâminas e para chapas de madeira compensadas existentes na norma IBDF/ABIMCE 1985, é possivel usar a madeira de Eucalyptus grandis na manufatura de compensados porém, seu uso deve ser restrito basicamente ao miolo dos painéis.

Atualmente, o processo de laminação de toras de Eucalyptus grandis, pode ser considerado satisfatōrio, porēm pesquisas devem. ser desenvolvidas principalmente nas áreas do manejo e melhoramento florestal visando a melhoria da qua lidade dos troncos. Considerando-se a experiēncia adquirida no decorrer deste trabalho e os resultados existentes na literatura, sugere-se que sejam desenvolvidos estudos para avaliar técnica e economicamente a aplicação das operações de desrama artificial e desbastes seletivos, visando obter toras de boa qualidade para a produção de lāminas.

Para as condições do Brasil, onde os povoamen tos existentes foram conduzidos para a produção de papel e 
celulose e as árvores selecionadas para serraria e laminação foram aqueles que apresentaram os melhores ritmos de crescimento e forma, sem a devida atenção para com as tensões internas de crescimento, a utilização das técnicas abordadas neste trabalho, apresenta-se, para o momento, como a melhor opção a curto prazo. Já a médio e longo prazo será importan te utilizar as sugestões de FERNANDES (1982), que visam a formação de plantios clonais a partir de exemplares selecionados para baixos indices de rachaduras, como também o desen volvimento de estudos visando a determinação da componente herdável da tendëncia de toras racharem no processamento mecânico. 


\section{CONCLUSÖES}

Com base na discussão dos resultados deste trabalho e na comparação com as informações disponíveis na literatura pode-se concluir que:

1. as tensões internas de crescimento causadoras das rachadu ras de topo ḑas toras de Eucalyptus grandis podem ser minimisadas através de técnicas adequadas;

2. o corte e a toragem das árvores de Eucalyptus grandis com anelamento diminui as rachaduras de topo;

3. os conectores metálicos anti-rachaduras do tipo Gang Nail restringem as ações das tensões internas de crescimento, porêm não são suficientes para conter as tensões de secagem; 
4. não houve progressão das rachaduras das toras armazenadas sob imersão e aspersão d'água;

5. há uma diminuição significativa das tensões internas de crescimento com o aumento do tempo de armazenamento das toras sob imersão total;

6. é possivel produzir lâminas das toras de Eucalyptus grandis, pelo processo de desenrolamento;

7. as lâminas de Eucalyptus grandis obtidas neste trabalho se prestam quase que exclusivamente para miolo na manufatura de compensados. 


\section{LITERATURA CITADA}

ANDRADE, E.N. de, 1961. O Eucalipto. 2. ed. Jundiai. CPEF. $667 \mathrm{p}$.

ASSOCIAÇÃO NACIONAL DE PAPEL E CELULOSE, 1984. Relatório Anual, São Paulo.

BARNACLE, J.E. e J.W. GOTTSTEIN, 1968. Control of end-splitting in round timber. A promising new method. Forest Products Technical Notes. CSIRO, Melbourne, (4).

BARRICHELO, L.E.G. e A.H. NARYOSHI, 1984. Variação das características da madeira de Eucalyptus para diferentes espécies, idades e locais. 17 \% Congresso Anual de Celulo se e Papel. São Paulo.

BOYD, J.D., 1950a. Tree growth stresses: I. Growth stresses evaluation. Australian Journal of Scientific Research. Serie B - Biological Sciencies. Melbourne. 3: 270-93. 
BOYD, J.D., 1950b. Tree growth stresses: II. The development of shakes and other visual farlures in Timber. Australian Journal of Applied Science. Melbourne, 1: 296312 .

BOYD, J.D., 1950c. The growth stresses: III. The origin of growth stresses. Australian Journal of Scientific.

Research. Série B - Biological Sciencies. Melbourne, 3: $294-309$.

BOYD, J.D., 1972b. The growth stresses: V. Evidence of an origin in differentiation and lignification. Wood Science and Technology, Berlin, 6: 251-62.

CARPIM, M.A. e L.E.G. BARRICHELO, 1984. Influência da proce dência e classe de diâmetro sobre as características da madeira de Eucalyptus grandis. 179 Congresso Anual de Ce lulose e Papel. São Paulo.

CHAPE, S.C., 1979. Growth Stress in Trees. Australian Forest Research. CSIRO, Melbourne, 9: 203-23.

CONFERENCIA MUNDIAL DO EUCALIPTO, 1961. 2. São Paulo. Relatório e documentos. São Paulo. FAO 2 v.

CONRADIE, W.E., 1980. Utilization of South African grown E. grandis. (W. Hill ex-Maiden) as veneer log - Pat 1. Control of end-splitting in veneer logs CSIR Special Report Hout. 260. National Timber Research Institute. Pretoria. 26 p. Oct. 
COSTA, T.G.M., 1961. Os Eucaliptos no planejamento da política florestal brasileira. São Paulo, Estrada de Ferro Central do Brasil. 7.p.

DINWOODIE, J.M., 1966. Growth stresses in timber: a review of literature. Forestry, London, 39(2): 162-70.

DOBIE, J., 1965. A review of los storage practices. British. Columbia Lunberman. Abr. $4 \mathrm{p}$.

EDWARDS, D.W., 1973. Defects of fast-grown in new South Wale Australia. In: IUFRO - 5. Meeting, 1973. Republic of South Africa Proceeding. Pretoria, Cape Town Stelienbosch.

FAO, 1981. Eucalyptus for Planting. Rome, FAO. p. 503. FEIHL, O. e E.V. GODIN, 1970. Peeling Defect in Veneer, their causes and control. Canadian Forestry Service. Otawa.

FERNANDES, P.S., 1982. Variação de densidade da madeira e suas relações com as tensões de crescimento em Progênie de E. urophylla S.T. Blake. Piracicaba, 85 p. (Tese de Mestrado - ESALQ/USP).

FERREIRA, M., 1973. Variação da densidade basica da madeira de plantações comerciais de Eucalyptus alba Reino (E. uro philla S.T. Blake), Eucalyptus saligna Smith e Eucalyptus. grandis. Hill ex-Maiden - VI. Convenção Anual ABCP. São Paulo. 
FREITAS, A.R. de e R.H. PONCE, 1979 - Madeira serrada de eucalipto. Jornal dos reflorestadores, são Paulo, $\underline{I}(2)$ : $24-5, a b r$.

GERALDO, F.C. E J.A.C. SODRE, 1983. A comparative study of some anti-splitting devices, using Eucalyptus saligna and híbridos of Eucalyptus saligna $\times$ Eucalyptus spp poles. The International Research Group on Wood Preservation. Austrälia.

GIORDANO, G. e P. CURRO, 1973. Observation concerning manual methods for redução demage from growth stresses in Eucalyptus sawn Timber. In: IUFRO. 5. Meeting, 1973. Republic of South Africa Proceeding Pretoria, Cafe Town Stellenbosch.

GIORDANO, F.G.; P. CURRO e G.R. CHISI, 1969. Contribution of the study of internal stresses in wood of Eucalyptus. Wood Science and Technology. New York, 3. p. 1-13.

HALL, R.D.J.N. e G.M. CHIPPENDATE, 1975. Forest trees of Australia. Australian Government Publishing Service. Camberra, $334 \mathrm{p}$.

HILLS, W.E., 1978. Wood quality ana utilization. In: HILLS, W.E. and BROWN, A.G. Eucalyptus for Wood Production CSIRO. Adelaide. $434 \mathrm{p}$. 
HILLS; W.E. e A.G. BROWN, 1978. Eucalyptus for Wood Production. CSIRO. Adelaide. $434 \mathrm{p}$.

IUFRO, 1973. Veneer species of the world: Working Part on slicing and Veneer cuting. Forest Products Laboratory, Wisconsin. $150 \mathrm{p}$.

JACOBS, M.R., 1938. The fibre tension of wood stems, with special reference to the genus Eucalyptus. Bull. Commonwealth Forestry Bureau, Canberra, (22): 7-37.

JACOBS, M.R., 1939. Further studies on fibre tension. Bull. Commonwealth Bureau, Canberra, (24): 7-34.

JACOBS, M.R., 1945. The growth stresses of wood stems. Bull. Commonwealth Forestry Bureau, Canberra, (28): 1-67.

JACOBS, M.R., 1965. Stresses and strains, in tree trunks as they growth in length and width. Leaflet. Commonwealth. of Australian Departament of National Development. Forestry and Rimber Bureau, Canberra (96): 1-15.

JANKOWSKY, I.P. e O.J.R. de AGUIAR, 1983. Manufatura de Paí néis Compensados com Eucalyptus: Caracterizaçăo de diver sas espécies. Revista Floresta. Curitiba, 14(1).

KOEHLER; A., 1933-A new hipothesis as to the cause shakes and rift cracks in Gree Timber. Journal of Forestry, Wisconsin, $31(5), 551-6$. 
KUBLER, H., 1959. Studies on growth stresses in trees: part 3-effect of heat treatment on the dimensions of green wood. Holz als roh - und Werkstoff. Berlin, 17: 77-86.

LUTZ, J.F., 1974. Techniques for Peeling slicing, and drying veneer. USDA. Forest Service. Research paper FPL, Visconsin (228): 1-63.

Mc MILLAN, W.P., 1978. Reconstituted Wood Products, In: HILLS, W.E. e BROWN, A.G. Eucalyptus for Wood Production. Adelaide, CSIRO, p. 318-23.

MALAN, F.S., 1979. The control and-splitting in saw logs: A short literature review. South African Forestry Journal, Pretoria, (109): 14-8.

MALAN, F.S., 1984. Studies on the phenotypic variation in growth. strees intensity and its association with tree and wood properties of South African Grow. Eucalyptus grandis. (Hill ex-Maiden). PhD Thesis, University of Stellenbosch.

NICHOLSON, J.E., 1971. A rapid method for estimating longitudinal Growth stresses in logs. Wood Science and Technology, New York, $\underline{5}: 40-8$.

NICHOLSON, J.E., 1973a. Effect of storage on growth stress in mountain ash logs trees. Australian Forestry, Victoria, $36(2): 115-24$. 
NICHOLSON, J.E., 1973b. Growth stress differences in Euca1yptus. Forest Science. 19: 169-74.

POST et alii. 1980. An extension of Jacobs method for measuring residual growth strains in logs. Wood Science and Technology. New York. 14: 289-96.

SIMÕES, J.W. et alii. 1981 Formação Manejo e Exploração de Florestas de Rápido Crescimento. IBDF, Brasilia, 131 p.

SKOMEN, R.G., 1966. Heating logs. To relieve growth stresses. Forest Products Journal Madison, 17(7).

TURNBUIL, R.F., 1965. Review of current attitudes to growth stresses. IUFRO - 5. Committee on Growth Stresses. Melbourne, $8 \mathrm{p}$.

VAN WYK, J.L., 1978. Hardwood sawmilling can have a bright future in South Africa. South African Forestry Journal, Pretoria, (109): 47-53. dez.

VILLIERS, A.M., 1973. Utilization problems with same Eucalypts in South Africa. IUFRO 5. South Africa, Pretoria, $238: 55$.

WATANABE, H., 1965. A study of the origin of longitudinal growth stresses in tree stens. IUFRO - 5. Committee on Growth Stresses. Melbourne $16 \mathrm{p}$. 
WILHELMY, V. e H. KUBLER, 1973 - Stresses and checks in log end from relived Growth Stresses. Wood Science. Madison $6(2):$ Oct. $136-142$ 